\title{
Fostering turnout?: Assessing party leaders' capacity to mobilize voters
}

Frederico Ferreira da Silva - European University Institute

\section{Introduction}

Recent research on voting behaviour has confirmed the existence of a trend towards candidate-centred politics. While long ago the media and public discourse had emphasized the role of individual political actors in contemporary politics, such claims had only found mixed evidence in empirical studies. More recently, a thorough consideration of the temporal dimension, the effort to develop comparative analyses, and both theoretical and methodological refinements, produced consistent evidence on the importance of leaders as determinants of vote choice (Garzia, 2014; Lobo and Curtice, 2015). However important, these contributions have moved straightforwardly to examining leaders' effects on vote choice without carefully considering their potential impact on the baseline decision to turn out to the ballot box. While leaders have been demonstrated to influence choice over different party options, this is likely to be preceded by an impact over turnout decisions. In impacting vote choice, leader effects can operate in two possible ways: a) capturing votes who otherwise would belong to his/her party's competitors or b) motivating individuals who otherwise would not vote at all to vote for his/her party. Therefore, just as party identification expresses a preference across parties which simultaneously drives individuals to vote and to select a given party rather than another, attitudes towards leaders could act in a similar fashion - if a leader is sufficiently appealing to influence vote choice, she also could be a driver of participation in the first place. 
At the policy-making level, the capacity of leaders to connect with the electorate, counterbalance disengagement trends and mobilize voters to go to the ballots seems to be more widely recognised, as illustrated by the recent Spitzenkandidaten initiative. In an attempt to increase turnout rates in the 2014 European Parliament elections, the European Parliament's political groups have decided to publicly support a lead candidate for the presidency of the European Commission. In what constitutes an example of the importance attributed to individual political actors in contemporary politics - even at the transnational level -, for the first time voters were given the possibility to have a say on which candidate they wanted ahead of the European Commission. Facing increasing Euroscepticism and disengagement in European elections, this was perceived as an effective strategy to enhance EU democracy and promote more participated elections in a context of personalization of politics.

The generalized decline in turnout rates across contemporary Western democracies is a symptom of the dealignment process at the origin of the personalization of politics, establishing a theoretical relationship for the mechanism through which leaders could impact turnout decisions. Yet, it is still to be determined to what extent can voters' evaluations of leaders have an effect on turnout. Likewise, studies on individual-level turnout have largely disregarded the role of political leaders in stimulating electoral participation.

This study aims to fill this gap shared by the personalization of politics and the turnout literature. In this way, it attempts to offer a contribution by drawing attention to the mobilizing potential of political leaders and discussing the possible relevance of a more frequent inclusion of variables accounting for voters' assessments of the candidates running for election in turnout models. 
The article proceeds as follows. The next section problematizes the relationship between turnout and the personalization of politics, shedding light on the potential mechanisms through which turnout rates can be affected by the performance of party leaders. The third section describes the data and methods used in the empirical analysis. The fourth section presents the main results, followed by a section including various robustness tests. Section 6 extends the results' section by exploring potential contextual effects of the political and electoral system as moderators. Finally, the conclusions of the study are discussed in the last section.

\section{Turnout and the personalization of politics: a missing link}

The personalization of politics refers to the process through which individual political actors have been gaining increased importance compared to political parties (Karvonen, 2010). Within the framework of this thesis, over the last decades we have been witnessing a tendency towards a greater preponderance of party leaders in the political arena (Wattenberg, 1991). This has been particularly notorious in the media discourse: political content is framed around the visible faces of political parties, executives became named after their leaders, personality profiles are thoroughly compared, and televised debates between party leaders are discussed by media pundits as a decisive factor to electoral outcomes. Also political parties have contributed to this trend by focusing their communication strategies in their leaders through the development of increasingly individualized campaigns (Lisi and Santana-Pereira, 2014; Zittel and Gschwend, 2008); broadening their leader selection procedures to wider selectorates, ultimately resulting in the proliferation of primaries in many European political parties (Cross and Pilet, 2016; Hazan and Rahat, 2010; Kenig, 2009); and enhancing the leader's role within the contemporary types of political parties by conceding them more power and autonomy to 
make individualized decisions (Lobo, 2008). At the electoral system level, numerous European countries have been implementing personalizing reforms, altering electoral rules so that citizens can express their preferences for candidates and have a greater decision-power over the allocation of seats (Renwick and Pilet, 2016). Lastly, multiple studies have demonstrated that voters' evaluations of political leaders have an effect on voting behaviour (Aarts, Blais, and Schmitt, 2011; Bittner, 2011; Garzia, 2013; Lobo and Curtice, 2015) and that this impact has been growing across time (Garzia, 2014; Garzia, Silva, De Angelis, 2018).

Despite recent studies having established that assessments of party leaders do have an impact on individual vote choice, research on the personalization of politics has not yet devoted attention to a former aspect of the voting decision process: the decision to turn out. The relationship between leader effects and vote choice has been drawn without any reflection on the intermediate stage when the voter decides whether to go to the polls or to refrain from voting. Since leaders were demonstrated to have an impact on voters' choices over different parties, it seems plausible that at least some of these voters are also driven to the polls by the appeal of political leaders.

The theoretical framework underlying research confirming leader effects on vote choice applies similarly to individual-level turnout. Individualization and the process of dealignment weakened the long-standing bonds between voters and political parties. Following the erosion of cleavages which structured voting behaviour, voters have become gradually detached from the set of social and political attitudes in the origin of party identification. With individualization, group-based ideological alignments on the basis of the political cleavages have faded. This has led voters to become increasingly unconstrained from the identification bonds resulting from previous alignments with political parties (Dalton and Wattenberg, 2002; Dalton, 2012). Dalton (2002, 30-31) 
estimates the number of individuals who identify with a political party to have declined, for example, about $18 \%$ in Sweden, $16 \%$ in the United States, $15 \%$ in Germany, and $14 \%$ in France, in just a few decades. Alignments, and the cleavages in their origin, conditioned not only vote choice but also turnout decisions. The determinants of turnout and vote choice have historically largely coincided, which is unsurprising since motivations on the grounds of decisions upon the latter are inevitably extensive to the former. Vote choice presupposes a coherent behaviour regarding turnout since it is impossible to choose between parties without having cast a vote, and the reasons which drive an individual to choose a party over another are very much associated with the reasons that lead him/her to turn out instead of abstaining. Therefore, it follows that a structural change in the determinants of the latter element of the voting calculus are tied to transformations in the more primary stage of the decision-making process. Thus, if rather than repeatedly following party heuristics, voters have become more sensible to short-term factors in their voting choice decisions - such as candidates or performance assessments -, the same factors are likely to determine turnout decisions.

Moreover, given the importance of dealignment as a key cause of the personalization of politics, and the fact that one of the most evident symptoms of this process has been the generalized decline in voter turnout rates across contemporary Western democracies (Blais and Rubenson, 2013), there are theoretical reasons to expect an effect of leader evaluations on turnout decisions. The few studies which have linked dealignment with leader effects have focused exclusively on whether leader evaluations have a higher impact on swing voters, late deciders or voters without party identification (Gidengil, 2011; Lobo, 2015). The turnout dimension of the dealignment process has been surprisingly neglected thus far, although an analysis of turnout decisions with a particular focus on the impact of party leaders appears to be theoretically pertinent. 
The potential of political leaders to act as mobilizing agents and foster turnout has recently been acknowledged by policy-makers at the European Union level. The elections for the European Parliament have historically been poorly participated, not reaching the $50 \%$ threshold of turnout since 1999. The decision for the Spitzenkandidaten strategy in the 2014 European Parliament elections, comes with a recognition of the potential of candidates to increase the salience of the elections and mobilize more voters to cast a ballot, "raising the turnout for European elections by strengthening the link between the elections of the representatives of the citizens with the selection and election process of the head of the European executive" (European Commission 2013, 6).

A recent study assesses the impact of this initiative on turnout decisions and finds a mobilizing effect of candidate recognition and campaign activity of the three most visible candidates on turnout; additionally, candidate recognition was also found to strengthen the impact of campaign activities on turnout (Schmitt, Hobolt, and Popa, 2015). Having found such effects in second-order elections, where arguably voters still had very limited awareness of the candidates running for election, it can be argued the effect could even be stronger in first-order elections. In the latter type, campaigns are more intense and personalized (canvassing is easier, the candidates are more familiar, their presence in the media is stronger, and TV debates assume a major importance) and voters are also more prone to be recipients of political messages and information.

Noticeably, also the individual-level turnout literature has disregarded the relationship between turnout and political leaders, whether measured through voters' evaluations of leaders' personality traits or general leader evaluation scales. Apart from studies on American presidential elections (Adams, Dow, and Merrill, 2006), the role of candidates in voters' turnout decisions in general elections has been largely ignored. This is puzzling given the importance early attributed by Campbell and his colleagues (Campbell et al., 
1960) to the general role of attitudes on voting behaviour and the specific consideration of attitudes towards candidates in their research. Furthermore, within the framework of these psychological models, attitudinal elements have often been demonstrated to be associated with turnout, as is the case with attitudes towards the EU (Kentmen-Cin, 2017) and voting and elections (Blais, 2014). Therefore, attitudes towards party leaders, as increasingly relevant actors in contemporary politics, could also play a role in citizens' turnout decisions. In this sense, also from the point of view of individual-level turnout literature, it would be relevant to assess to what extent do leaders impact turnout decisions.

This study explores this missing link by taking a step back in the decision-making process and addressing the effects of voters' evaluations of party leaders on turnout decisions, hypothesizing that positive evaluations of leaders stimulate individuals to participate in elections. In addition, in line with previous research that demonstrated that, on vote choice, leaders may have a differentiated impact across respondents' degree of dealignment (Gidengil, 2011; Lobo, 2015), it tests whether such leader effects on turnout are stronger on particularly dealigned voters, i.e., those lacking a party identification. Further, it also tests whether these effects are stronger for individuals who have been abstaining in past elections. The reasoning being that individuals who did not vote for the previous election are more likely to be structurally dealigned and thus more influenced by factors such as political leaders rather than party evaluations. With these theoretical expectations in mind, the following hypotheses can be formulated:

H1: Voters' evaluations of party leaders have a positive effect on their probability to turn out

H2: Leader effects on turnout are particularly impactful on independent voters 
H2.1.: Leader effects on turnout are inversely related to voters' degree of party identification

H2.2.: Leader effects on turnout are stronger among voters who have abstained in the previous election

Wattenberg $(2002,71-72)$ estimates turnout rates to have declined, for example, around $19 \%$ in France, $15 \%$ in the United States, and $11 \%$ in the United Kingdom and Germany over the last half century. If leaders are found to have a mobilizing potential and the capacity to motivate individuals who otherwise would exclude themselves from participating in elections to vote, the personalization of politics may be argued to play a beneficial role in reconnecting voters with politics. Furthermore, the dealignment process would not necessarily mean a definitive large-scale retreat from politics but could be attenuated or even partially reversed by the positive effect of leaders.

In addition to the advanced hypotheses, a second body of expectations can be added regarding the potential moderating role of political and electoral systems on leaders' impact on turnout decisions. In line with findings from previous studies who found leader effects to be stronger in presidential contexts (Curtice and Hunjan, 2011; Curtice and Lisi, 2015), the existence of differences in leader effects across different political systems is explored. In addition, following Balmas et al. (2014) theoretical distinction between centralized and decentralized personalization, electoral systems' features favouring decentralized personalization are considered, as the latter type of personalization may depress party leader effects. In specific, it is explored a) whether (semi-)presidential regimes' institutional design is more favourable to the existence of leader effects on turnout; b) whether smaller district sizes are harmful to party leader effects on turnout; 
and c) whether the possibility to cast a personalized vote dampers leader effects on turnout. A further theoretical account of these relationships and the empirical results of this exploratory analysis are provided in Section 6.

Details on the dataset, variables and overall analytical strategy used to test the hypotheses follow in the next section.

\section{Data and methods}

\subsection{Variable selection}

Given the variety of theoretical approaches to the study of individual-level turnout in contemporary democracies, difficulties arise to build a balanced model which is still able to account for the multitude of factors impacting turnout decisions. Unsurprisingly, a large number of covariates are frequently included in turnout models. However, since this is a thoroughly studied topic with results accumulated as a consequence of several decades of quality research, it is now possible to select the most accurate predictors in order to build parsimonious and informative models.

Recently, Smets and van Ham (2013) have conducted a meta-analysis of individual-level research on voter turnout, accounting for 90 studies published over the first decade of this century on ten top-journals in political science and political behaviour. In this relevant contribution the authors analyse over 170 different independent variables and rate them as a result of their performance in the studies analysed. The authors consider six models of turnout: the resource model focuses on the conditioning role of voters' resources in determining their participation; the mobilization model explores the mobilizing ability of 
parties and other interest groups in driving turnout; the socialization model emphasizes the role of socialization in the formation of political attitudes and behaviours; rational choice models highlight the cost-benefit calculus of turning out to vote; the psychological model centres around voters' cognitive characteristics; and the institutional model explores the influence of the political system on citizens decisions to vote.

Smets and van Ham define a variable's success rate as a result of a ponderation of its successes $^{1}$ and the number of tests including this variable. ${ }^{2}$ For the present study, the variables with a success rate over $60 \%$ were pre-selected to be included in the individuallevel turnout model, largely covering the abovementioned streams of literature. This threshold was established for theoretical reasons since many of these variables do no longer hold theoretical pertinence; methodological reasons, since from a model estimation point of view parsimonious models tend to be preferable; and practical reasons, because the larger the number of covariates, the more likely it is that they are not going to be present in all election studies considered, thus harming comparability efforts. Admittedly, this decision comes with some caveats such as not taking into account effect size but only statistical significance, although the authors come up with a proxy measure of average effect size.

\subsection{Dataset and variable description}

\footnotetext{
1 "In the vote-counting procedure, each test of a hypothesis is considered a 'success' when a coefficient is statistically significant and has the hypothesized direction. On the other hand, the hypothesis test is considered a 'failure' when it is found not to be significant and an 'anomaly' when the coefficient is statistically significant but is in the opposite direction than expected.” (Smets and van Ham, 2013, 346)

${ }^{2}$ success rate $=($ sucesses $/$ number of tests $) * 100$
} 
The data used in this analysis is derived from the Comparative Study of Electoral Systems (CSES), a collaborative project which gathers data from worldwide post-electoral surveys through the incorporation of a common module in the National Election Studies (NES) of participant countries. Each country's module is then compiled in the common dataset, allowing for data comparability on elections carried in a wide range of countries across similar time periods. The full releases of modules 3 (2006-11) and 4 (2011-16) were used, yielding a total of 50 election studies from 25 Western democracies - a full list of countries, election years and respective sample sizes is available in Appendix 1. ${ }^{3}$

Additionally, whenever a pertinent variable was missing from the CSES study for a specific country, in order not to exclude this country or sacrifice the model by excluding relevant variables, a more recent version of the data from that country's NES was used. Every time the NES had the missing variable it substituted the country sample of the CSES, to have more complete and up to date data - this was the case with Spain ${ }^{4}$.

The harmonization of a large number of election studies from several countries under a common framework provided by the CSES was the main reason to prefer this dataset. This facilitates cross-country analysis in comparative studies, while providing quality data on the relevant independent variables to test this study's propositions. It also avoids potential language barriers faced when collecting NES individually. Nevertheless, due to its comparative nature, the set of variables contained in the CSES modules is somewhat restricted and this constrains the number of possible covariates to be featured in the

\footnotetext{
${ }^{3}$ Countries which enforce compulsory voting were not included. Italy (2013) and the UK (2010) were added to the sample through their respective NES.

${ }^{4}$ In CSES Module 3 Spain was missing the "turnout on the previous election". Spain was also missing the variable referring to the organisational membership.
} 
model. For example, media exposure and socio-economic status were relevant variables according to the pre-established criteria but could not be included in the model because they were unavailable.

Based on the previously established threshold based on Smets and van Ham (2013), the following variables were included (a full list of the variables, their measurements and summary statistics is available in Appendix 2). The dependent variable turnout dichotomizes individuals who have voted from those who have not (0: Did not vote; 1 : Voted). Age was divided into age groups (1: Less than 30; 2: 30-39; 3: 40-49; 4: 50-59; 5: 60-69; 6: More than 70), gender as 1: Male and 2: Female, and education into 1: no formal education, 2: primary education, 3 : secondary education, and 4: tertiary education - these were the only socio-demographic variables added, given the decrease in the explanatory power of these variables documented in the literature and the fact that these were the only variables from the resource model surpassing the pre-defined criteria. Organizational membership, from the mobilization model, was built from a compound index of the following dichotomous questions (0: No; 1: Yes): "Are you a member of a union?", “Are you a member of a business or employers' association?”, “Are you a member of a farmers' association?", and “Are you a member of a professional association?". Whenever the respondent answered positively to at least one of these questions organizational membership was coded as 1; if the respondent always answered negatively organizational membership was coded as 0 . Turnout on the previous election refers to rational choice models and is the most powerful control. Voting is a learning and habit-forming process and hence having voted on previous elections minimizes the costs of voting for current elections and repeatedly reinforces the probability to vote along the life course. Past voting is usually highly predictive of current turnout, especially when it reports to the last elections held. It was dichotomized into 0: did not vote in the previous 
elections and 1: voted on the previous election. Strength of party identification was coded as follows: not having a party identification (0), not very close (1), somewhat close (2), and very close (3). Political efficacy ${ }^{5}$ was measured through the question "Who people vote for makes a difference?" and political sophistication ${ }^{6}$ was built out of three political knowledge questions identical across CSES electoral studies. These three variables are categorized into psychological models.

Political attitudes towards parties and leaders, from rational choice models, were operationalized in the variables rating of the respondent's most liked party ${ }^{7}$ and rating of the respondent's most liked leader. The CSES - as all the NES used - asks respondents to rate each party and leader running for election on a $0-10$ like-dislike scale, leading to a set of different variables measuring each party/leader's likeability. From a modelling perspective, including one variable per each leader and party would render the results incomparable across countries and impossible to interpret. Instead, the strategy employed was to take the value of the party and leader highest rated, among all options for each country, and create the most liked leader and party variables. Besides, it seems reasonable to assume that, in principle, if any party or leader is to have an impact on turnout decisions that will be the party or leader most liked by the respondent.

\footnotetext{
${ }^{5}$ Scale from 1: Who people vote for won't make a difference to 5: Who people vote for can make a big difference.

${ }^{6} 0$ : All answers incorrect; 1: One correct answer; 2: Two correct answers; 3: All answers correct. In Module 4, four political knowledge questions were available, rather than three. To mirror the procedure adopted for Module 3, only the first three of these questions were considered.

${ }^{7}$ This variable was not available in the Spanish and the Italian National Election Studies. Propensities to vote were used in its place and coded in the same way.
} 


\subsection{Independent variables}

The use of leader like-dislike scales has been preferred over the use of variables capturing leaders' personal attributes solely due to methodological constraints, as there is no reason to assume that the same kind of relationship would not hold had the latter been used instead. Nevertheless, the inclusion of variables tapping leaders' personal attributes in European election studies (which constitute core focus of the argument) is very limited. Its use over like-dislike scales would result in a very restricted sample of countries. Since the aim of this study is to demonstrate the widespread importance of leader evaluations for turnout decisions in contemporary Western democracies, a large-N comparative approach has been privileged. Furthermore, such an approach would not be possible using the CSES dataset. As such, important advantages for comparative studies such as having harmonized variables using the same question wording across countries would have to be discarded. Finally, the availability of like-dislike scales for both leaders and parties allows for direct comparisons between them using the same measurement scales, which would be impossible using personal attributes. In sum, despite acknowledging the potentials of a framework including leaders' personal attributes, using like-dislike scales serves better the overall purpose of the study.

Using like-dislike scales to measure both party and leader evaluations also allows to capture for short-term variations in party and leader likeability, which are not measured through party identification variables, designed to reflect the stability of an enduring affective relationship. In the context of pronounced decline of party identification over the past decades, larger shares of the electorate have been reporting not having an identification with any political party (Dalton, 2002). However, a considerable share of these individuals continues to vote, to nurture interest for politics, and even to be quite politically sophisticated (Dalton, 2012). Non-identifiers have been shown to make short- 
term assessments of the performances of political parties and candidates and take them into account in their voting decision (Fiorina, 1981). The increase of swing voters and late deciders also demonstrates the growing consideration of short-term assessments (Dalton, 2012; Lavine, Johnston and Steenbergen, 2012; Lobo, 2015). In conclusion, a substantial part of the electorate does not have enduring loyalty bonds with political parties and therefore its proximity to political parties cannot be measured on a long-term basis. The considerable number of voters without an identification with a political party is noticeable in this study's data, although with some variation among election studies (Figure 1).

Figure 1 - Distribution of strength of party identification by election study




For this reason, the use of likeability scales for both party and leader evaluations gains pertinence because it can account for the volatility of party preferences and apply to types of voters who do not have a party identification. These range from the disengaged voter who sporadically is mobilized by a party or leader, to the politically independent assiduous voter whose ballot is not promised to any party or leader beforehand but is contingent on progressive assessments made on the run.

Moreover, the joint consideration of party and leader evaluations is important from a theoretical point of view, given the everlasting debate about party and leader effects, and their possible interdependence. Despite an overwhelming majority of studies particularly the most recent ones - providing evidence in favour of the personalization of politics, there are also some studies finding only limited effects, or a stronger effect of party attachments on voting behaviour (e.g. Curtice and Hunjan, 2011; Holmberg and Oscarsson, 2011). The same can be argued regarding election campaigns (Kriesi, 2012; Wilke and Reinmann, 2001). Hence, the phenomenon is not entirely undisputed, as parties are still an importance reference, at least to some voters. Therefore, it is still important to consider the role parties may still hold and its interplay with leader evaluations.

Finally, the use of like-dislike scales is sometimes criticized because of being a relative measure, varying according to each individual's subjective value attribution to each point of the scale. Moreover, it has been argued that it is unclear which factors voters actually do consider when they rate parties or leaders based on their likeability, casting some doubts about what exactly is being measured (Fiorina 1981, 154). This distortion problem, named Differential Item Functioning (DIF), has been most notoriously addressed by Aldrich and McKelvey (1977) and, more recently, Hare et al. (2015). To account for this issue, two different measures of leader evaluations - an absolute and a relative - and their vulnerability to DIF were considered (see section 5.2. for a detailed 
description of the measures). While the absolute measure was halved when accounting for latent perceptual distortions, the relative measure remained virtually unaltered. In any case, the identification of a strong convergence between the two measures (as in Figure 5, section 5.2.) relaxes concerns regarding DIF.

\subsection{Analytical strategy}

Regarding the model estimation strategy adopted in next section, logistic regression models with fixed election-study effects were used. These models are suitable for this type of large- $\mathrm{N}$ analysis because they account for different sample sizes and country/election-study specificities which could produce biased the estimates. In this way, the differences in time and among countries across election studies are controlled for. As reported at the end of the results' section, the estimations were subjected to leaveone-out cross-validation tests to check for outliers which might be driving the results. The results from section 4 were also subjected to an extensive battery of robustness tests in section 5 , focusing on alternative measurements of the key variables (leader and party evaluations, as well as party identification) and subjects' ex-post rationalization on reported evaluations.

In section 6, instead, the model estimation strategy considered contextual moderator variables at the election-study level, introduced to explore the existence of differences in effects across political and electoral systems. For this reason, this time a multilevel model estimation was employed. Random-slopes were also included to gauge eventual variation in effect size across election studies.

\section{Results}


The analyses are based on a logistic regression with fixed country effects for a total of 50 election studies from 25 countries. Five models were tested: model 1, including all the covariates but the party and the leader like-dislike scale; model 2, including the party likedislike scale; model 3 including the leader like-dislike scale (and removing the party); model 4, including all the covariates plus the party and leader evaluation variables; and model 5, adding two interaction terms combining leader evaluations with strength of party identification and turnout on the previous election. A step-by-step approach to the model was preferred because it allows to observe how the party and leader evaluations variables perform both independently and together. This is desirable given the previously mentioned high correlation between them and the literature debate concerning the importance of parties vis-à-vis leaders for the vote. The results are presented in Table 1 and show a significant positive effect of voters' evaluations of political leaders on turnout.

The results from the model 1 largely reflect what has been established in the literature. Turnout behaviour on the previous election is the strongest predictor of current turnout. In fact, this is the variable with the highest impact across all the models estimated. This was expected and comes in line with the literature perceiving voting as a self-reinforcing habit formation process - once an individual has voted before, the costs of voting (namely concerning information barriers, in certain cases registration, etc.) in subsequent elections are lower, for example. Two sorts of concerns can be raised at this point regarding previous turnout's high estimates. The first is associated with the risk of tautological claims that turnout is explained by turnout (in the past). The second relates to the possible correlations between previous turnout and the remaining covariates - in particular, much of partisanship's variance may be captured by previous turnout. To address these concerns, all models were re-estimated without turnout in the previous election. The 
results, in Appendix 3, rebut such concerns, as the effects of the key predictors are only slightly altered.

The degree of party identification and political sophistication appear to also have a strong effect on turnout. The direction of the effect is as expected, placing the individuals with stronger long-term attachments with a given political party as more likely to cast a vote, as well as individuals with a higher degree of political sophistication.

Model 2 introduces voters' evaluations of their most liked party on a 0 to 10 likeability scale. This variable differs from party identification because it may reflect short-term attitudes towards political parties, whereas party identification reflects a stable attachment based on a long-term psychological identification with a political party, rooted in early socialization (Campbell et al., 1960). In this sense, a voter may have a long-term identification with a given party but presently be unsatisfied with that party's performance and like other more. Alternatively, she may not have a party identification at all, but at a given moment in time like a political party more than its competitors and be driven to vote by that feeling. These evaluations may be shaped by a number of contextual factors such as retrospective or prospective evaluations of parties' performances, chosen candidates, political events, etc. According to revisionist theories of party identification as a running tally (Fiorina, 1981), these short-term assessments may later on consubstantiate in transformations at the party identification level but they are primarily distinct from the concept of party identification. This distinction is confirmed by the moderate correlation (.38) between the two variables in the dataset. Party evaluations are significant and have a substantial effect size: for each point increase in the party likeability scale, the chances of turning out to vote increase by $21 \%$. 
Table 1 - Logistic regression model of leader effects on turnout with fixed election-study effects ( 25 countries)

\begin{tabular}{|c|c|c|c|c|c|c|c|c|c|c|}
\hline & \multicolumn{2}{|c|}{ Model 1} & \multicolumn{2}{|c|}{ Model 2} & \multicolumn{2}{|c|}{ Model 3} & \multicolumn{2}{|c|}{ Model 4} & \multicolumn{2}{|c|}{ Model 5} \\
\hline & OR & OR $95 \% \mathrm{CI}$ & OR & OR $95 \% \mathrm{CI}$ & OR & OR $95 \% \mathrm{CI}$ & OR & OR $95 \% \mathrm{CI}$ & OR & OR $95 \% \mathrm{CI}$ \\
\hline \multicolumn{11}{|l|}{ Age (groups) } \\
\hline \multicolumn{11}{|c|}{ Ref. category $=$ Less than 30} \\
\hline $30-39$ & $\begin{array}{l}1.09 * \\
(.05)\end{array}$ & $1.01-1.19$ & $\begin{array}{c}1.13 * * \\
(.05)\end{array}$ & $1.04-1.24$ & $\begin{array}{l}1.09 * \\
(.05)\end{array}$ & $1.00-1.19$ & $\begin{array}{c}1.12 * * \\
(.05)\end{array}$ & $1.03-1.23$ & $\begin{array}{c}1.13 * * \\
(.05)\end{array}$ & $1.03-1.23$ \\
\hline $40-49$ & $\begin{array}{c}1.34 * * * \\
(.06)\end{array}$ & $1.23-1.46$ & $\begin{array}{c}1.40 * * * \\
(.06)\end{array}$ & $1.28-1.53$ & $\begin{array}{c}1.34 * * * \\
(.06)\end{array}$ & $1.23-1.46$ & $\begin{array}{c}1.39 * * * \\
(.06)\end{array}$ & $1.27-1.52$ & $\begin{array}{c}1.39 * * * \\
(.06)\end{array}$ & $1.27-1.52$ \\
\hline $50-59$ & $\begin{array}{c}1.51 * * * \\
(.07)\end{array}$ & $1.38-1.65$ & $\begin{array}{c}1.58 * * * \\
(.07)\end{array}$ & $1.44-1.73$ & $\begin{array}{c}1.51 * * * \\
(.07)\end{array}$ & $1.38-1.66$ & $\begin{array}{c}1.57 * * * \\
(.07)\end{array}$ & $1.43-1.72$ & $\begin{array}{c}1.58 * * * \\
(.07)\end{array}$ & $1.44-1.73$ \\
\hline $60-99$ & $\begin{array}{c}1.87 * * * \\
(.09)\end{array}$ & $1.70-2.06$ & $\begin{array}{c}1.95 * * * \\
(.10)\end{array}$ & $1.77-2.15$ & $\begin{array}{c}1.82 * * * \\
(.09)\end{array}$ & $1.65-2.00$ & $\begin{array}{c}1.91 * * * \\
(.10)\end{array}$ & $1.73-2.11$ & $\begin{array}{c}1.93 * * * \\
(.10)\end{array}$ & $1.74-2.13$ \\
\hline More than 70 & $\begin{array}{c}1.61 * * * \\
(.08)\end{array}$ & $1.46-1.79$ & $\begin{array}{c}1.64 * * * \\
(.09)\end{array}$ & $1.48-1.83$ & $\begin{array}{c}1.56 * * * \\
(.08)\end{array}$ & $1.40-1.73$ & $\begin{array}{c}1.61 * * * \\
(.09)\end{array}$ & $1.44-1.79$ & $\begin{array}{c}1.63 * * * \\
(.09)\end{array}$ & $1.46-1.81$ \\
\hline Gender & $\begin{array}{l}1.06^{*} \\
(1.03)\end{array}$ & $1.00-1.12$ & $\begin{array}{l}1.02 \\
(.03)\end{array}$ & $.97-1.08$ & $\begin{array}{l}1.04 \\
(.03)\end{array}$ & $.99-1.10$ & $1.02(.03)$ & $.97-1.08$ & $.1 .02(.03)$ & $.97-1.08$ \\
\hline Education & $\begin{array}{c}1.32 * * * \\
(.03)\end{array}$ & $1.27-1.37$ & $\begin{array}{c}1.35 * * * \\
(.03)\end{array}$ & $1.30-1.41$ & $\begin{array}{c}1.34 * * * \\
(.03)\end{array}$ & $1.29-1.40$ & $\begin{array}{c}1.36 * * * \\
(.03)\end{array}$ & $1.31-1.41$ & $\begin{array}{c}1.36 * * * \\
(.03)\end{array}$ & $1.30-1.41$ \\
\hline Political efficacy & $\begin{array}{c}1.35 * * * \\
(.01)\end{array}$ & $1.32-1.37$ & $\begin{array}{c}1.29 * * * \\
(.01)\end{array}$ & $1.26-1.32$ & $\begin{array}{c}1.30 * * * \\
(.01)\end{array}$ & $1.27-1.33$ & $\begin{array}{c}1.28 * * * \\
(.01)\end{array}$ & $1.26-1.31$ & $\begin{array}{c}1.29 * * * \\
(.01)\end{array}$ & $1.26-1.32$ \\
\hline Strength of PID & $\begin{array}{c}1.62 * * * \\
(.02)\end{array}$ & $1.57-1.67$ & $\begin{array}{c}1.38 * * * \\
(.02)\end{array}$ & $1.34-1.43$ & $\begin{array}{c}1.47 * * * \\
(.02)\end{array}$ & $1.42-1.51$ & $\begin{array}{c}1.37 * * * \\
(.02)\end{array}$ & $1.33-1.42$ & $\begin{array}{c}1.39 * * * \\
(.02)\end{array}$ & $1.34-1.43$ \\
\hline Org. membership & $\begin{array}{c}1.29 * * * \\
(.05)\end{array}$ & $1.20-1.39$ & $\begin{array}{c}1.28 * * * \\
(.05)\end{array}$ & $1.19-1.38$ & $\begin{array}{c}1.28 * * * \\
(.05)\end{array}$ & $1.19-1.38$ & $\begin{array}{c}1.28 * * * \\
(.05)\end{array}$ & $1.18-1.37$ & $\begin{array}{c}1.28 * * * \\
(.05)\end{array}$ & $1.18-1.37$ \\
\hline Pol. sophistication & $\begin{array}{c}1.37 * * * \\
(.02)\end{array}$ & $1.33-1.42$ & $\begin{array}{c}1.35 * * * \\
(.02)\end{array}$ & $1.31-1.40$ & $\begin{array}{c}1.35 * * * \\
(.02)\end{array}$ & $1.31-1.39$ & $\begin{array}{c}1.35^{* * *} \\
(.02)\end{array}$ & $1.31-1.39$ & $\begin{array}{c}1.35 * * * \\
(.02)\end{array}$ & $1.30-1.39$ \\
\hline $\begin{array}{l}\text { Turnout on the } \\
\text { previous election }\end{array}$ & $\begin{array}{c}7.13 * * * \\
(.21)\end{array}$ & $6.72-7.55$ & $\begin{array}{c}6.28 * * * \\
(.20)\end{array}$ & $5.91-6.68$ & $\begin{array}{c}6.55 * * * \\
(.20)\end{array}$ & $6.18-6.96$ & $\begin{array}{c}6.23 * * * \\
(.20)\end{array}$ & $5.85-6.62$ & $\begin{array}{c}6.06 * * * \\
(.20)\end{array}$ & $5.69-6.46$ \\
\hline Party evaluations & & & $\begin{array}{c}1.21 * * * \\
(.01)\end{array}$ & $1.19-1.22$ & & & $\begin{array}{c}1.17 * * * \\
(.01)\end{array}$ & $1.15-1.19$ & $\begin{array}{c}1.16^{* * * *} \\
(.01)\end{array}$ & $1.15-1.18$ \\
\hline Leader evaluations & & & & & $\begin{array}{c}1.16^{* * * *} \\
(.01)\end{array}$ & $1.14-1.17$ & $\begin{array}{c}1.05^{* * * *} \\
(.01)\end{array}$ & $1.04-1.07$ & $\begin{array}{c}1.03 * * * \\
(.01)\end{array}$ & $1.01-1.05$ \\
\hline
\end{tabular}


Leader*Strength PID

Leader*Previous

turnout

N

AIC

61961

59974

60690

$.96 * * *$

(.01)

$.95 * *$

$.95-.98$

BIC

38570.57

36015.03

36978.34

59574

(.01)

$.93-.98$

McFadden's R2

39085.52

36537.12

37501.13

35661.16

59574

35623.85

36191.87

36172.55

0.29

0.29

0.29

$* p<.05 ; * * p<.01 ; * * * p<.001$

Standard errors between parenthesis

In model 5, the interacting variables are mean centered 
In model 3, voters' evaluations of their most liked party were replaced by voters' evaluations of their most liked leader, which proves to have a statistically significant impact on turnout. This results in only a small increase of the effect size of the degree of party identification, still quite distant from the coefficient of model 1 . The other covariates remain almost unchanged. The most important conclusion to draw from the comparison of the results of model 3 with model 2 relates to the similar effect size of party and leader evaluations. This suggests that short-term evaluations of leaders vis-à-vis parties are of similar importance for turnout: for each point increase in the leader likeability scale, the chances of turning out to vote increase by $16 \%$.

Inasmuch as leaders are perceived as secondary when compared to political parties, what is tested in model 4 - when party and leader evaluations are included simultaneously consists of a fairly strong test for the impact of leader evaluations on turnout. The fact that leader evaluations are still significant and have a non-negligible effect on turnout, despite probably being underestimated because of its relationship with party evaluations, attests the relevance of this variable for turnout models. 
Figure 2 - Effect of leader evaluations on turnout (Average Adjusted Probabilities, model 4)

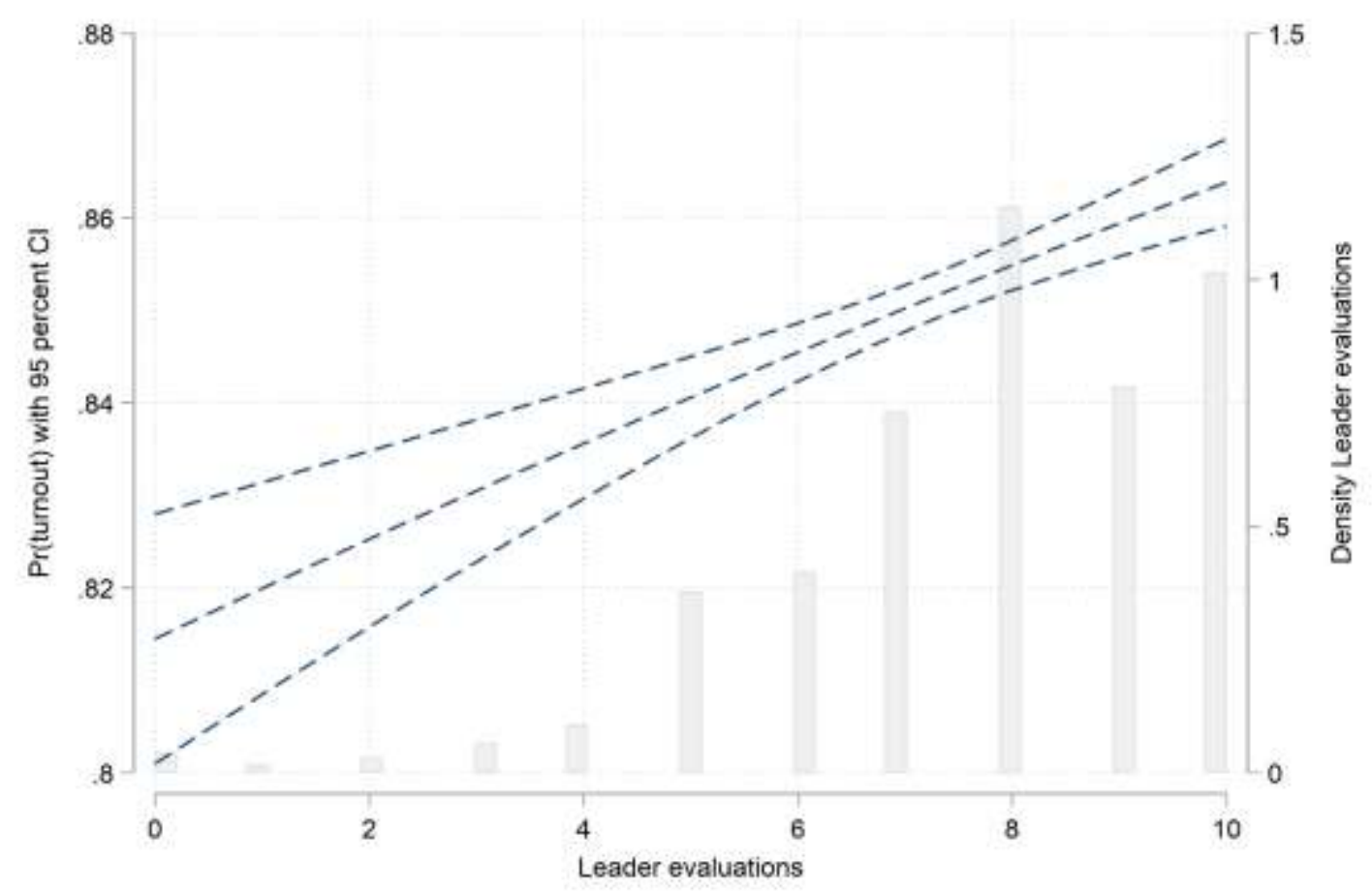

The marginal effect of this relationship is plotted in Figure 2. The increase in the probability to turn out for an average individual who rates his preferred leader on the first point of the scale (0) compared to an average individual who rates his preferred leader on the last point of the scale (10) is of about 8 percentage points. The histogram in the background of Figure 2 reflects the distribution of the leader evaluations variable. The distribution is substantially skewed towards the higher values of the scale given the nature of the variable, which intentionally selected each respondent's most liked leader. Despite the lower amount of cases in the first points of the scale, this did not affect too much the confidence intervals. Hence, leader evaluations do have a relevant impact on the probability to turnout regardless of the introduction of strong controls such as party evaluations, party identification and turnout on the previous election. These results 
confirm H1 and point towards the inclusion of voters' assessments of candidates in turnout models as a relevant explanatory variable.

4.1. Interaction effects: the moderator effect of party identification and past turnout

Model 5 provides a more refined assessment of the effect of leaders on turnout by adding interactions terms to the previous models. Previous research has demonstrated that voters without party identification are more detached from partisan bonds and thus are more likely to consider short-term factors such as the personal appeal of political leaders in their vote choice decisions (Lobo, 2015). To test if the same applies to turnout decisions, leader evaluations were interacted with respondents' degree of party identification. This interaction was found to be significant, demonstrating that leader effects on turnout are particularly strong among individuals without party identification (Figure 3 ). In fact, as expected based on dealignment theory, leader evaluations appear to be relatively irrelevant for voters who nurture strong bonds with political parties. Conversely, for those without party identification - and, to a lesser degree, for those with weak partisan attachments -, the effect of leader evaluations on turnout decisions is fairly strong. This is a relevant finding since it points towards possible positive normative implications of the personalization of politics. Leaders seem to be particularly able to catalyse the most disengaged voters and, as such, their mobilizing potential may prove normatively desirable.

Figure 3 - Interaction effects between leader evaluations and strength of party identification (Marginal effects, model 5) 


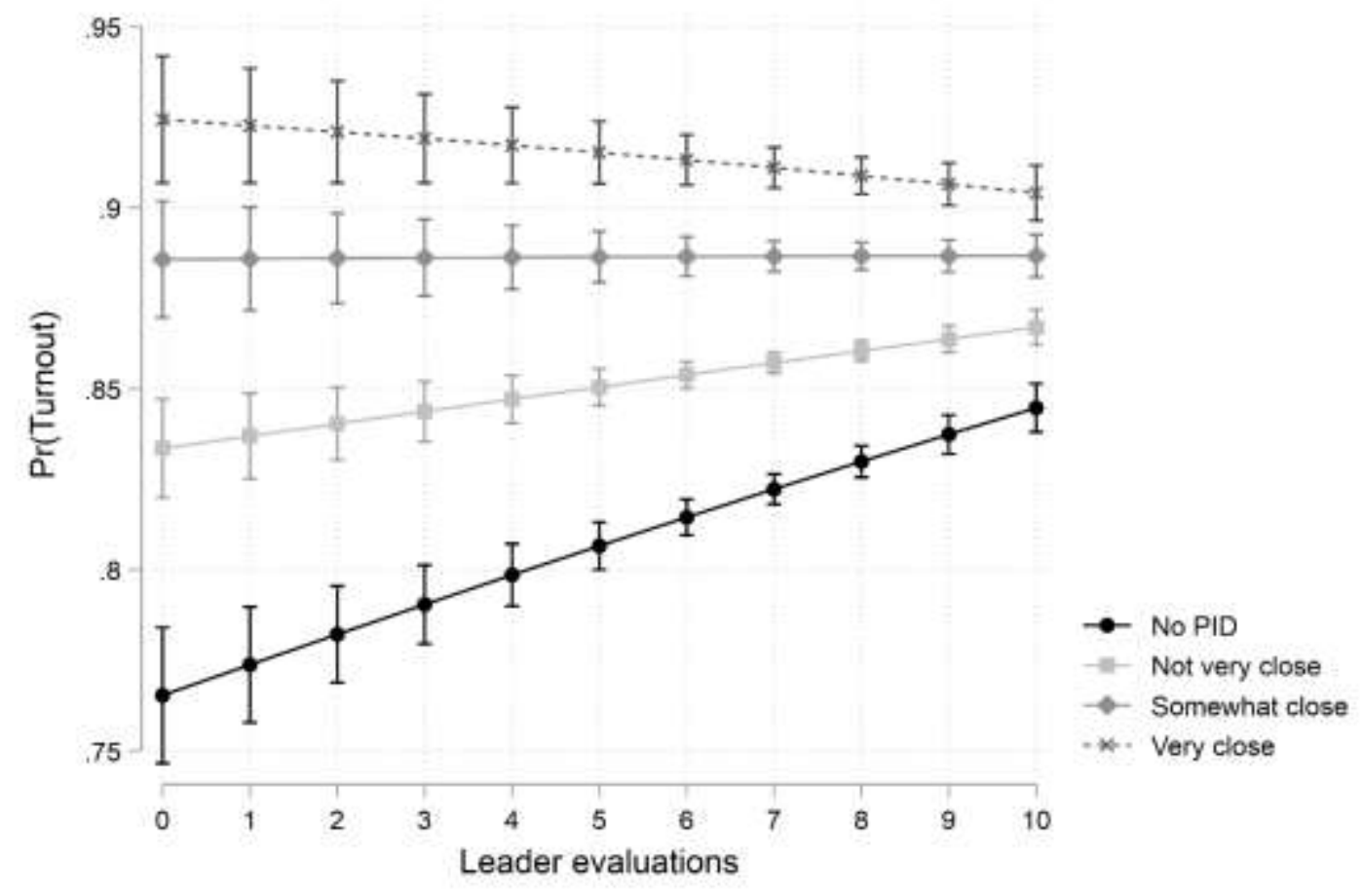

Still within the framework of dealignment theory, an interaction between leader evaluations and turnout on the previous election was tested. This interaction is also significant and the dissimilar effects among the two subgroups are clear (Figure 4). While the effect of leader evaluations on the probability to turn out remains fairly stable among the individuals who turned out on the previous election, there is a substantial increase, of more than 10 percentage points, on the probability to turn out among those that did not vote on the previous election. This suggests that leader evaluations are a strong factor in captivating abstainers and bringing back to voting individuals who have been abstaining for more than one election. 
Figure 4 - Interaction effects between leader evaluations and turnout on the previous election (Marginal effects, model 5)

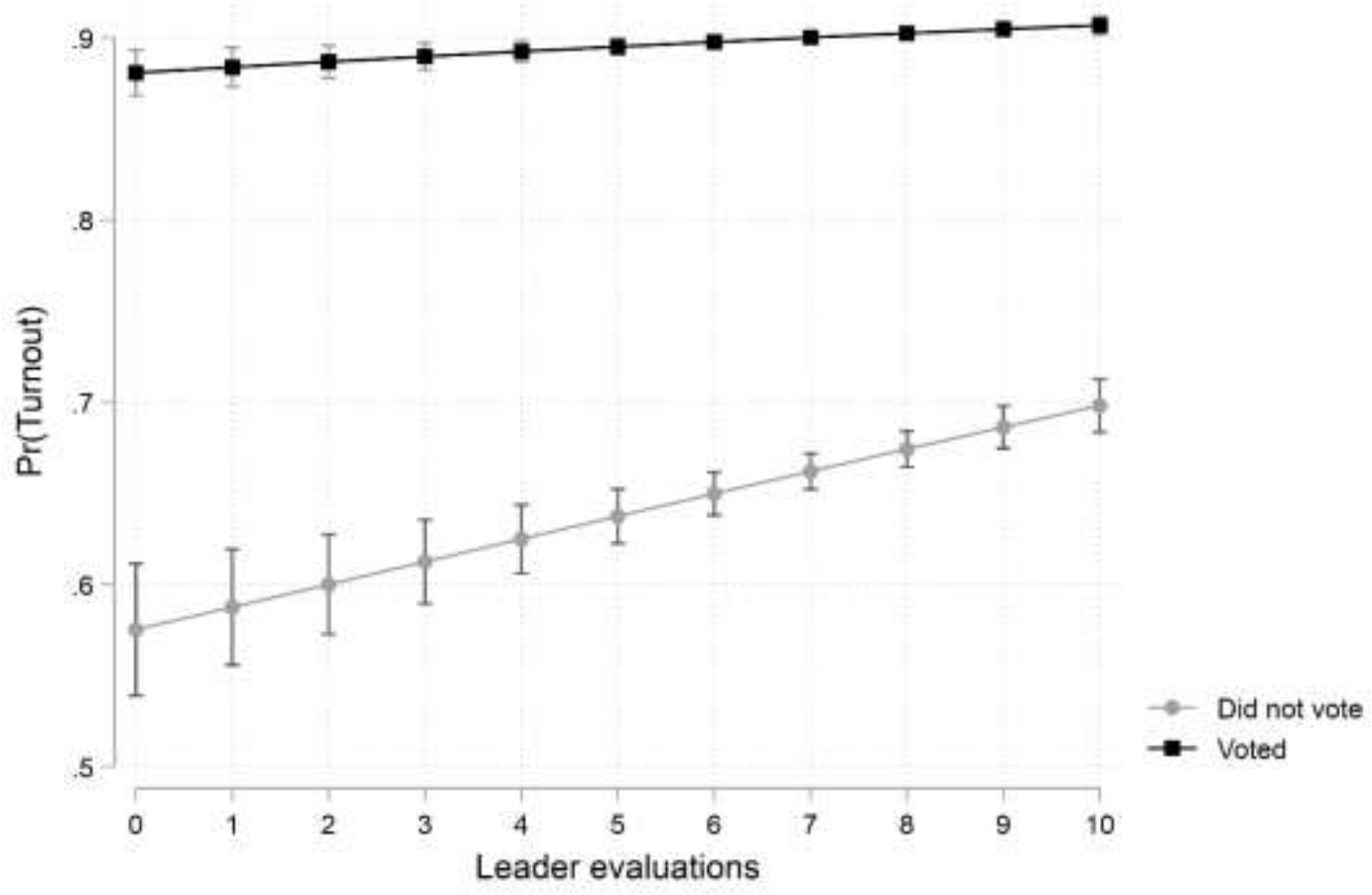

The results from both interactions confirm H2.1. and H2.2. and are indicative of the relationship between dealignment and the personalization of politics. Leader evaluations are especially relevant for dealigned voters who do not possess a longstanding attachment to a political party, or who have been abstaining for more than one election. Hence, while the personalization of politics was, to a great extent, a result of the process of dealignment, it can also play a role in attenuating its negative impacts, by promoting a reengagement of the most alienated segments of the electorate.

The results regarding the main effects of leader evaluations on turnout and both interaction effects reported have been subjected to leave-one-out cross-validation checks (see appendixes 6, 7 and 8 for coefficient plots). These tests exclude each election study 
at the time from the sample to detect if the results substantially changed, i.e., if they were being driven by potential outliers. All reported results proved robust to this test. ${ }^{8}$

The next section presents an extensive battery of robustness tests concerning the findings presented so far.

\section{Robustness tests}

\subsection{Dichotomous measurement of party identification}

It could be argued that the impact of party identification is likely to be more accurately measured in binary terms. According to this logic, what would matter for the likelihood to turn out is if an individual has a party identification, and not the intensity of this identification. If this is true, a more refined measurement may be contributing to an underestimation of its effect. In order to assess if this is occurring, the strength of party identification variable was replaced by a dichotomous measurement of party identification (0: Does not identify with a party; 1: Identifies with a party). The standardized coefficients of party and leader evaluations were almost identical, as

\footnotetext{
${ }^{8}$ In addition to the models presented in this section, an additional interaction model analysing the potential moderating effect of political sophistication on turnout was estimated in conjunction with the two previous interactions (Appendix 10). Political sophistication has been considered a relevant moderator variable by previous studies (e.g., Bittner, 2015; Gidengil, 2011; Lachat, 2015). The interaction term deemed positive and significant, suggesting that more sophisticated individuals are more likely to be mobilized by party leaders. Nevertheless, in this case the model did not survive the leave-one-out cross-validation test - the Slovenian election study of 2011 was found to be driving the results (Appendix 9). For this reason, this interaction was excluded from the models. In any case, it remains a relevant finding that leader evaluations were found not to vary according to voters' political sophistication.
} 
depicted in the regression output from Appendix 4. In fact, the dichotomous measure of party identification results in a higher coefficient for leader evaluations.

\subsection{Alternative measurement of leader effects}

The original measurement used in the previous models selected the leader respondents liked the most out of all the candidates running for election in their country at a given point in time. This could be considered an absolute measurement of leader effects. However, previous studies point to the importance of testing different measurements of leader effects (Mughan, 2015). An alternative measurement could be the difference between the most liked leader and the average of all leaders running for election in that country, in that year. This could be considered a relative measurement of leader effects which would capture how extraordinarily voters consider this leader compared to the other contenders. This is useful since some voters can have the tendency to rate all or most leaders similarly high (or low). Thus, the models were reran replacing the absolute by the relative measurement of leader effects, which, for each respondent, subtracts the mean of the leader evaluation variable from the rating of the most liked leader. The model comparison in Figure 5 shows that the differences between the two measurements are only minor and, most importantly, both reveal a significant positive impact of leaders on turnout. 
Figure 5 - Absolute and relative measurements of leader effects: model comparison, standardized

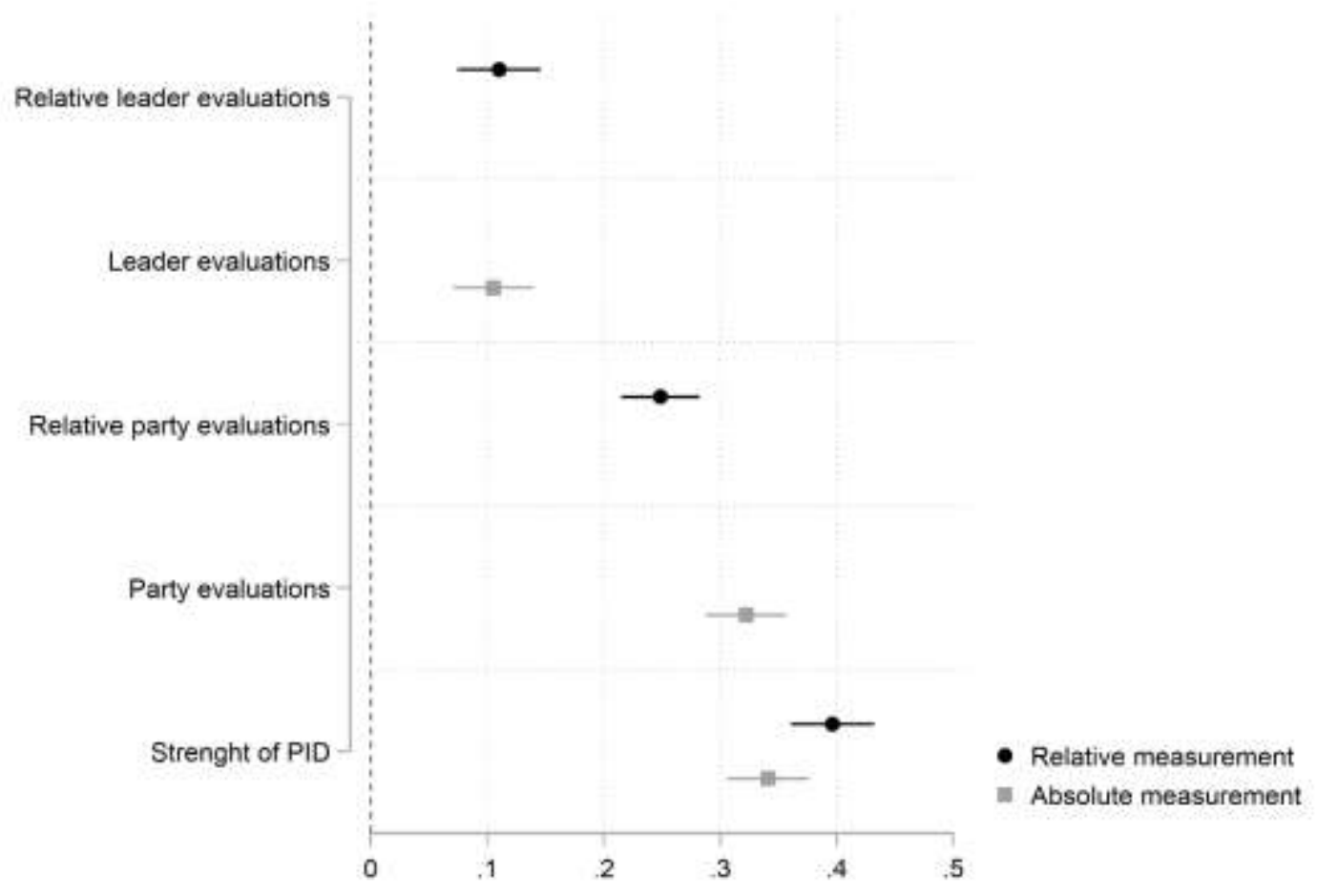

\subsection{Least liked leaders}

A proposition that has so far been untested relates to the possibility that, besides having a positive effect of turnout because voters strongly like them, leaders could also drive individuals to vote because they strongly dislike them. Examples of this kind abound in the literature on strategic voting but they are essentially directed at political parties (Downs, 1957). In a context of increasing personalization - particularly affecting populist/radical parties where the leader plays a prominent role, but also in mainstream parties in light of growing polarization (Lachat, 2015) -, some voters could be driven to the polls because they utterly dislike a candidate and want to prevent him from winning the election (Aarts \& Blais, 2012). Hence, additional models were estimated including absolute and relative measurements of the most disliked leaders - reversing the procedure 
(and scale) used before for the most liked leaders. These were estimated for model 4 (Figure 6) and in combination with the previous measurements (Appendix 5). ${ }^{9}$

Both measurements of disliked leaders proved to have a meaningful and significant impact on turnout. The effect is particularly strong for the relative measurement. In the case of disliked leaders, the absolute measurement is probably less effective in capturing the kind of effects just described, as it may erroneously capture the common setting where a respondent ascribes a certain rating to her preferred leader and rates all other leaders equally bad - in this setting, there would hardly be an effect of disliked leaders on turnout. Instead, the relative measurement of the disliked leader depicts a setting where a leader is negatively distinguishable from the average of all other leaders (the liked and the relatively indifferent ones), what further motivates individuals to turn out against him. ${ }^{10}$

\footnotetext{
${ }^{9}$ Appendix 5 provides an estimation of the marginal effects of disliked leaders (absolute and relative measurements) while controlling for most liked leaders (absolute and relative measurements), and viceversa. Thus, the estimates are the same as in Figure 6, but including the correspondent like-dislike measurement as a control.

10 The existence of feelings of indifference towards party leaders was also considered. Indifferent individuals would be those evaluating leaders with a 5 on the $0-10$ scale. However, the amount of those individuals was found not to exceed $9 \%$ of the sample. Given their relatively residual character, no further analysis was performed with regard to these individuals.
} 
Figure 6 - Marginal effects of most liked and disliked leaders (model 4)

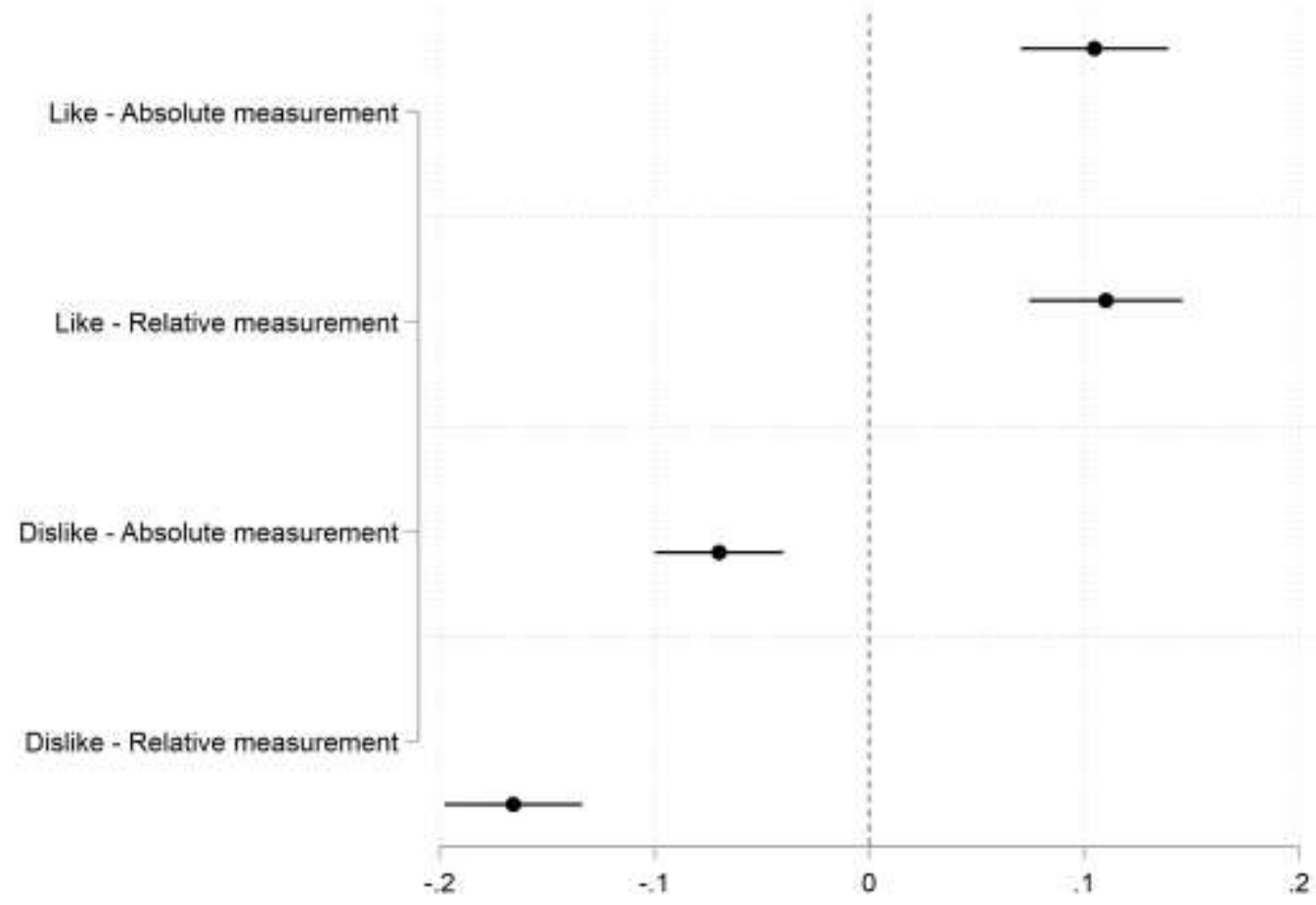

\subsection{Pre-post assessment}

A frequent critique to existing research on leader effects concerns the possibility of expost rationalization by individuals. To put it simply, because most studies use data collected in post-electoral surveys, voters may be driven to adjust their answers to the actual outcome of the election. Lewis-Beck, Nadeau and Elias (2008) have documented this issue regarding economic voting, for example. If the same occurs with voters' evaluations of candidates, the data collected after the election is inconsistent with what voters had in mind when they made their voting decisions and therefore, is inapt to explain voting behaviour.

A possible strategy to assess if this is happening consists in using panel data and comparing individuals' ratings of leaders before and after the election (Garzia and De Angelis, 2016). The more similar these ratings are, the surer one can be that what is being 
observed is not an adjustment as a consequence of the electoral results. CSES data is purely cross-sectional and therefore such a test cannot be performed for the entire sample. However, some of the countries in the sample have panel data comprising pre and postelectoral measurements in their national election studies. Data from Spain, the United Kingdom and the United States, referring to the same years as the ones in the sample, and thus the same individuals (but interviewed pre and post electorally), was used to perform this test.

The main test consists of re-estimating model 4 both pre-electorally and post-electorally. For the results to hold, the post-electoral coefficients for leader evaluations should be no higher than the pre-electoral ones. In addition, three other indicators were used: the correlation between the most liked leader variable and turnout pre-electoral; the correlation between the most liked leader variable and turnout post-electoral; and the correlation between the pre and the post measurement of the most liked leader. Again, ideally the post-electoral measures should correlate with turnout no higher than the preelectoral ones. Additionally, the pre*post correlation should be rather high, indicating a strong congruence between pre and post-electoral ratings.

The results from Table 2 confirm the expectation that the electoral impact of leaders does not correspond to ex-post rationalizations from voters. First, the regression models clearly show higher estimates for pre-electoral leader evaluations across all countries but Spain, where the coefficients are precisely the same pre and post-electorally. This provides rather strong evidence against any sort of ex-post rationalization. In addition, pre and postelectoral measurements of leader evaluations correlate fairly high in all four election studies, providing strong indications that what is being measured is the same. Furthermore, the correlation between pre and post-electoral leader evaluations and turnout is very similar across the four countries. Also, in general pre-electoral 
measurements correlate slightly higher with turnout, whereas one should expect postelectoral measurements to correlate higher in the case of ex-post rationalization.

A supplementary test was carried by taking the within-individual variation in leader evaluations across pre and post-electoral waves and estimating its impact on turnout. To be sure, such strategy was used to investigate whether such increase in an individual's most liked leader's rating, possibly driven by ex-post rationalization, affects the probability to turn out. The coefficient for the within-individual change in leader evaluations deemed not significant in both Spain and the United Kingdom, and significant $(p=.047)$ with a small effect in the United States. Hence, in general these changes are irrelevant to predict turnout and therefore concerns regarding a possible ex-post rationalization effect can be relaxed.

Table 2 - Pre-Post assessment of leader effects in selected countries: logistic model coefficients (model 4) and correlations between pre and post measurements of leader evaluations and turnout 
$* p<.05 ; * * p<.01 ; * * * p<.001$

6. The moderator role of the political and electoral system: an exploratory analysis

\begin{tabular}{lccc}
\hline & Spain & United Kingdom & United States \\
\hline Regression models & $.04 * * *$ & $.11^{* * *}$ & $.34^{* * *}$ \\
Pre-electoral & $.04 * * *$ & $.09 * * *$ & $.21^{* * *}$ \\
Post-electoral & n.s. & n.s. & $.08^{*}$ \\
Within-individual variance (pre-post) & & & .17 \\
Correlations & .36 & .22 & .16 \\
Pre*turnout & .30 & .27 & .71 \\
Post*turnout & .50 & .46 & \\
Pre*post & & & \\
\hline
\end{tabular}

In this section, an exploratory analysis of the differences of leader effects on turnout across political and electoral systems is carried out. Certain features of political and electoral systems may provide more (un)favourable conditions for the existence of leader effects on turnout. This calls the need to consider possible contextual variations that may affect the extent to which leaders have a mobilizing potential. The objective is therefore to identify whether leader effects on turnout can vary according to three types of factors: the regime type, the size of the electoral districts, and the possibility to cast a personalized vote.

The institutional design of presidential systems is argued to favour a candidate-centered type of politics. Increased leadership autonomy from the legislature, unipersonal executive responsibility, and popular election of the head of government are features that contribute to a perception of higher leadership profile among voters and the media in presidential countries (Poguntke \& Webb, 2005). Contrarily, in parliamentary systems, it is claimed to prevail the notion of the Prime-Minister as a primus inter pares, much due 
to the collective executive responsibility and the fact that the executive emerges and is contingent on the confidence of the legislature, making it still very much the arena of party organizations. For example, Curtice and Hunjan (2011), as well as Curtice and Lisi (2014), found evidence of a weaker impact of leaders on vote choice in parliamentary regimes compared to presidential ones. The hybrid semi-presidential design, while on the one hand including some elements of presidential systems which could play in favour of the personalization hypothesis, on the other hand is also characterized by power-sharing dynamics between the President and the Prime-Minister which may downplay the perceived profile of party leaders.

The rationale underlying the consideration of the size of the electoral districts and the possibility to cast a personalized vote is related to the concept of decentralized personalization. In their seminal article, Balmas et al. $(2014,37)$ distinguish between centralized and decentralized personalization, the latter referring to the cases where the "power flows downwards from the group to individual politicians who are not party or executive leaders", such as candidates. Wauters et al. (2016) demonstrate how these two processes often involve a zero-sum logic: centralized personalization often emerges at the expenses of decentralized personalization and vice-versa. Thus, this is an important aspect to take into account, as contexts highly favourable to decentralized personalization may damper centralized personalization, namely in the form of leader effects on turnout. Regarding district size, in smaller districts leaders could be argued to matter less, given that possible proximity connections with local politicians might overshadow party leaders. The same kind of rationale can be applied to settings where a personalized vote for a given candidate is made possible.

To assess if the results concerning leader effects on turnout can be influenced by these factors, in Table 3, model 4 was used as a baseline model for re-estimation as to account 
for the political and the electoral system. In specific, in model 6 a cross-level interaction between leader evaluations and the type of regime (0. Parliamentary; 1. SemiPresidential $^{11}$; 2. Presidential) was added. As per the electoral system, in model 7 an interaction between leader evaluations and the electoral district $\operatorname{size}^{12}$ (number of seats) was included, and model 8 accounts for the electoral system's possibility of casting a personalized vote (0: No; 1 : Yes). Cross-level interactions between the most liked leader variable and the contextual moderators were added in a random slope model (Table 3)

\footnotetext{
${ }^{11}$ Semi-Presidential countries were coded according to Elgie (2011) and an updated version of this piece by the author (2017) available at: http://www.semipresidentialism.com/?p=1053

${ }^{12}$ Data unavailability led to the exclusion of Spain (2011), United Kingdom (2010), Slovakia (2016), Serbia (2012), Italy (2013), Montenegro (2012) and France (2012) from model 7 and Spain (2011), United Kingdom (2010), Slovenia (2011) and Italy (2013) from model 8.
} 
Table 3 - The moderator role of the political and electoral system characteristics on leader effects on turnout: random effects models

\begin{tabular}{|c|c|c|c|c|c|c|}
\hline & \multicolumn{2}{|c|}{ Model 6} & \multicolumn{2}{|c|}{ Model 7} & \multicolumn{2}{|c|}{ Model 8} \\
\hline & OR & $95 \% \mathrm{CI}$ & OR & $95 \% \mathrm{CI}$ & OR & $95 \% \mathrm{CI}$ \\
\hline \multicolumn{7}{|l|}{ Age (groups) } \\
\hline \multicolumn{7}{|l|}{$\begin{array}{l}\text { Ref. category = Less } \\
\text { than } 30\end{array}$} \\
\hline $30-39$ & $\begin{array}{l}1.12 * \\
(.05)\end{array}$ & $1.03-1.22$ & $\begin{array}{c}1.21 * * * \\
(.06)\end{array}$ & $1.09-1.33$ & $\begin{array}{l}1.19 * * * \\
(.06)\end{array}$ & $1.08-1.31$ \\
\hline $40-49$ & $\begin{array}{c}1.38 * * * \\
(.06)\end{array}$ & $1.26-1.51$ & $\begin{array}{l}1.52 * * * \\
(.08)\end{array}$ & $1.37-1.68$ & $\begin{array}{c}1.47 * * * \\
(.07)\end{array}$ & $1.34-1.62$ \\
\hline $50-59$ & $\begin{array}{c}1.57 * * * \\
(.07)\end{array}$ & $1.43-1.72$ & $\begin{array}{c}1.66^{* * *} \\
(.09)\end{array}$ & $1.50-1.85$ & $\begin{array}{c}1.64 * * * \\
(.08)\end{array}$ & $1.48-1.81$ \\
\hline $60-99$ & $\begin{array}{c}1.90 * * * \\
(.10)\end{array}$ & $1.72-2.10$ & $\begin{array}{c}2.06^{* * *} \\
(.12)\end{array}$ & $1.85-2.31$ & $\begin{array}{l}2.01 * * * \\
(.11)\end{array}$ & $1.81-2.24$ \\
\hline More than 70 & $\begin{array}{l}1.60 * * * \\
(.09)\end{array}$ & $1.43-1.78$ & $\begin{array}{c}1.74 * * * \\
(.11)\end{array}$ & $1.54-1.97$ & $\begin{array}{c}1.68 * * * \\
(.01)\end{array}$ & $1.49-1.88$ \\
\hline Gender & $1.02(.03)$ & $.97-1.08$ & $\begin{array}{l}1.00 \\
(.03)\end{array}$ & $.94-1.07$ & $\begin{array}{l}1.01 \\
(.03)\end{array}$ & $.96-1.08$ \\
\hline Education & $\begin{array}{c}1.36 * * * \\
(.03)\end{array}$ & $1.30-1.41$ & $\begin{array}{c}1.43 * * * \\
(.04)\end{array}$ & $1.36-1.50$ & $\begin{array}{c}1.40 * * * \\
(.03)\end{array}$ & $1.34-1.47$ \\
\hline Political efficacy & $\begin{array}{c}1.29 * * * \\
(.01)\end{array}$ & $1.26-1.32$ & $\begin{array}{c}1.35^{* * * *} \\
(.02)\end{array}$ & $1.32-1.38$ & $\begin{array}{l}1.33 * * * \\
(.02)\end{array}$ & $1.30-1.36$ \\
\hline Strength of PID & $\begin{array}{c}1.37 * * * \\
(.02)\end{array}$ & $1.32-1.41$ & $\begin{array}{c}1.38 * * * \\
(.03)\end{array}$ & $1.33-1.43$ & $\begin{array}{c}1.36 * * * \\
(.02)\end{array}$ & $1.32-1.41$ \\
\hline Org. membership & $\begin{array}{c}1.29 * * * \\
(.05)\end{array}$ & $1.20-1.39$ & $\begin{array}{l}1.29 \\
(.06)\end{array}$ & $1.18-1.41$ & $\begin{array}{l}1.30 * * * \\
(.06)\end{array}$ & $1.20-1.42$ \\
\hline Pol. sophistication & $\begin{array}{c}1.34 * * * \\
(.02)\end{array}$ & $1.30-1.39$ & $\begin{array}{c}1.34 * * * \\
(.03)\end{array}$ & $1.29-1.39$ & $\begin{array}{c}1.33 * * * \\
(.02)\end{array}$ & $1.28-1.38$ \\
\hline $\begin{array}{l}\text { Turnout on the } \\
\text { previous election }\end{array}$ & $\begin{array}{c}6.22 * * * \\
(.20)\end{array}$ & $5.85-6.62$ & $\begin{array}{l}5.82 * * * \\
(.20)\end{array}$ & $5.43-6.23$ & $\begin{array}{c}6.11 * * * \\
(.20)\end{array}$ & $5.73-6.53$ \\
\hline Party evaluations & $\begin{array}{c}1.17 * * * \\
(.01)\end{array}$ & $1.15-1.19$ & $\begin{array}{c}1.13 * * * \\
(.01)\end{array}$ & $1.11-1.15$ & $\begin{array}{c}1.13 * * * \\
(.01)\end{array}$ & $1.11-1.16$ \\
\hline Leader evaluations & $\begin{array}{c}1.11 * * * \\
(.01)\end{array}$ & $1.08-1.14$ & $\begin{array}{c}1.07 * * * \\
(.01)\end{array}$ & $1.04-1.08$ & $\begin{array}{c}1.06 * * * \\
(.01)\end{array}$ & $1.03-1.08$ \\
\hline Political system & $\begin{array}{l}.68 * * \\
(.09)\end{array}$ & $.51-.89$ & & & & \\
\hline District size & & & $\begin{array}{l}1.00 \\
(.00)\end{array}$ & $.98-1.01$ & & \\
\hline Personalized vote & & & & & $\begin{array}{l}.72 * \\
(.11)\end{array}$ & $.53-.96$ \\
\hline \multicolumn{7}{|l|}{ Leader*Pol.system } \\
\hline Semi-Pres. & $\begin{array}{l}.92 * * * \\
(.01)\end{array}$ & $.89-.94$ & & & & \\
\hline Presidential & $.96(.04)$ & $.89-1.04$ & & & & \\
\hline Leader*District size & & & $\begin{array}{l}1.00 * \\
(.00)\end{array}$ & $1.00-1.00$ & & \\
\hline $\begin{array}{l}\text { Leader*Personalized } \\
\text { vote }\end{array}$ & & & & & $.99(.01)$ & $.97-1.03$ \\
\hline
\end{tabular}




\begin{tabular}{|c|c|c|c|c|c|c|}
\hline Var(political system) & $.44(.10)$ & $.28-.70$ & & & & \\
\hline Var(district size) & & & $.00(.00)$ & $.00-.00$ & & \\
\hline $\begin{array}{l}\text { Var(personalized } \\
\text { vote) }\end{array}$ & & & & & $.56(.14)$ & $.35-.90$ \\
\hline $\operatorname{Var}($ constant $)$ & $.31(.08)$ & $.18-.52$ & $.54(.14)$ & $.32-.90$ & $.37(.11)$ & $.21-.66$ \\
\hline$N$ (individuals) & \multicolumn{2}{|c|}{59574} & \multicolumn{2}{|c|}{47263} & \multicolumn{2}{|c|}{51846} \\
\hline$N$ (groups) & \multicolumn{2}{|c|}{45} & \multicolumn{2}{|c|}{38} & \multicolumn{2}{|c|}{41} \\
\hline$A I C$ & \multicolumn{2}{|c|}{35694.64} & \multicolumn{2}{|c|}{27741.91} & \multicolumn{2}{|c|}{30454.06} \\
\hline$B I C$ & \multicolumn{2}{|c|}{35877.54} & \multicolumn{2}{|c|}{27908.42} & \multicolumn{2}{|c|}{30622.32} \\
\hline
\end{tabular}

$* p<.05 ; * * p<.01 ; * * * p<.001$

Standard errors between parenthesis

The results from Table 3 are mixed. Concerning the influence of the regime type, in model 6 the interaction between leader evaluations and the type of regime results negatively significant only with regard to semi-presidential systems, partially rejecting $\mathrm{H} 3$. This regime type seems less favourable to the existence of leader effects on turnout. As argued before, this could be due to the fact that, as Sartori (1997) put it, semi-presidential systems operate in a power sharing basis within a dual authority structure. This may contribute to take the spotlight away from party leaders or Prime-Ministers, since the political arena is shared with Presidents. The non-significant interaction with presidential regimes is probably associated with the fact that only one country (two elections) in the entire sample is a presidential democracy. This interaction effect was plotted in Figure 7.

Figure 7 - Interaction effects between leader evaluations and regime type (Marginal effects, model 6) 


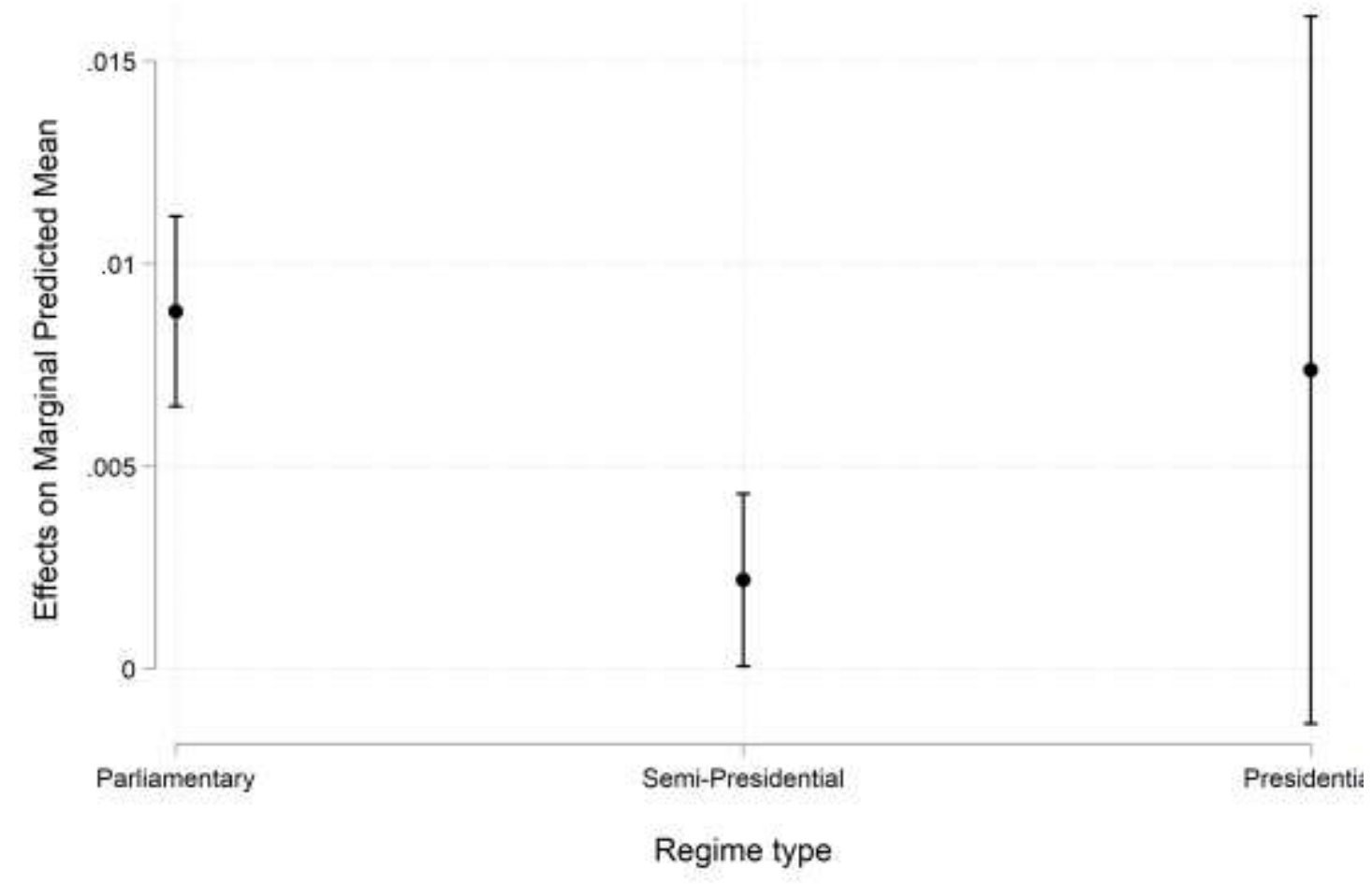

Regarding the other interactions, in model 7 the interaction with the electoral district's size is significant. However, the magnitude of the effect deems it virtually irrelevant. Also, there is almost no variance in the random slope at the district size level. Looking at the plotted effects in Figure 8, it becomes clear that the moderating effect of this variable is inexistent, as all variation falls within the confidence intervals. Therefore, although statistically significant, the substantial significance of this variable is irrelevant. Finally, in model 8 leader evaluations were interacted with the possibility to cast a personalized vote. This relationship was found not to be significant. In sum, the characteristics of the electoral system which could potentially downplay centralized personalization in favour of decentralized personalization have no substantial effects, at least regarding the impact of voters' evaluations of party leaders on their turnout decisions, thus rejecting H4.1. and H4.2. 
Figure 8 - Interaction effects between leader evaluations and size of the electoral district (Marginal effects, model 7)

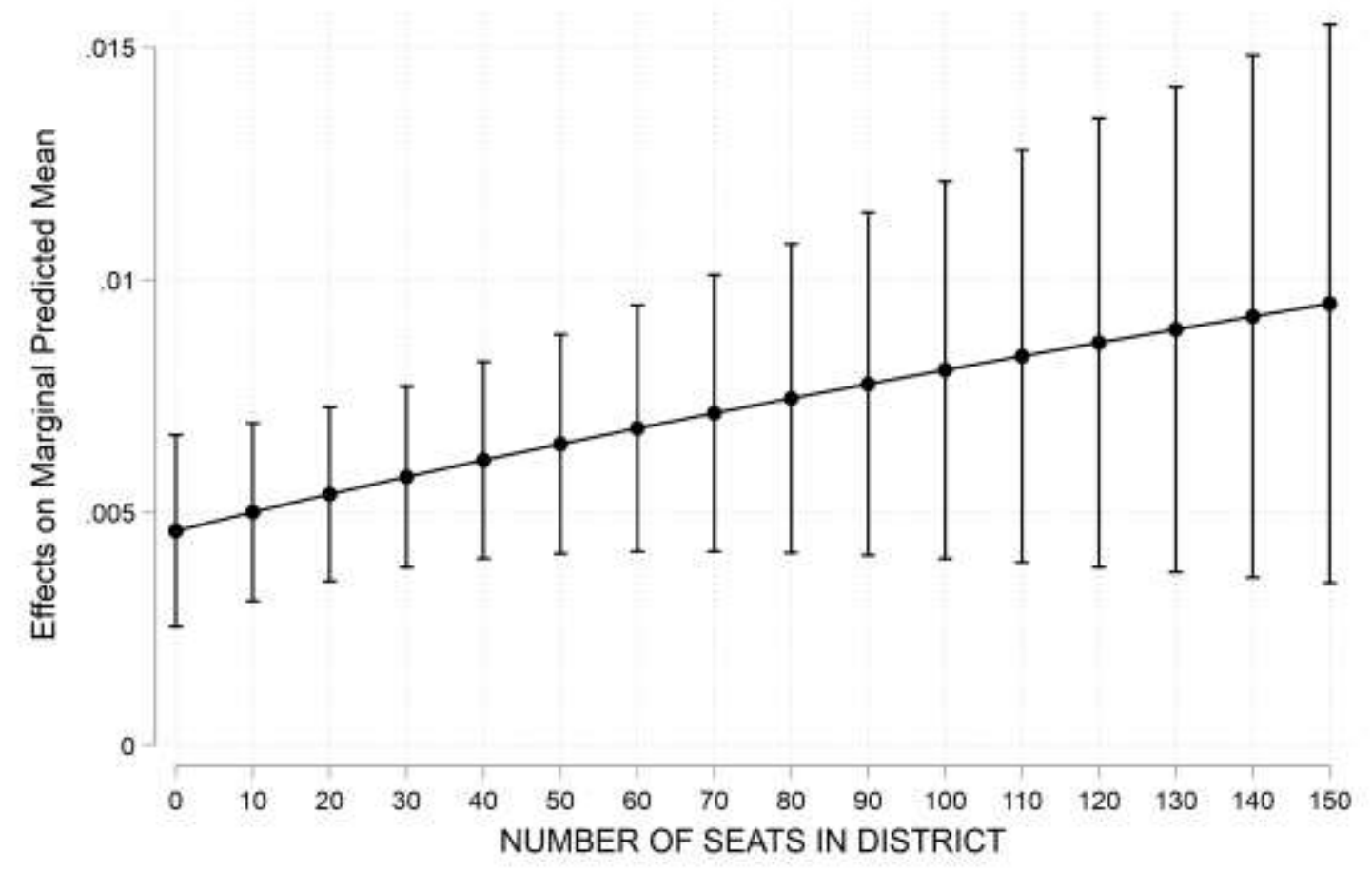

\section{Discussion and conclusions}

This study aimed at assessing the importance of voters' evaluations of political leaders on turnout with a two-fold objective: on the one hand, demonstrate that leaders have a potential as mobilizing political agents and thus the personalization of politics can have positive normative implications for contemporary democracies; on the other hand, by providing evidence of a general trend common to several Western democracies where leaders have an effect on turnout, call for a more frequent consideration of variables related to candidates in turnout models.

The results have confirmed the hypothesis that leaders have an effect on turnout. Leaders were found to matter and to have a substantial impact on the probability to turn out in parliamentary elections. This 25-country analysis reveals that this trend is transversal 
across several Western democracies. As parties still retain most of their traditional mobilizing function, party leaders also carry a considerable mobilization potential in current elections.

Furthermore, the mobilizing potential of leaders was found to be particularly notorious amongst the most dealigned voters. Individuals who lack attachments to political parties and individuals who have abstained in the previous election are the ones most impacted in their turnout decisions by assessments of party leaders. While the personalization of politics has often been portrayed as an overall negative phenomenon for contemporary democracies, leaders' effective appeal to the most structurally disengaged segments of the electorate might counterbalance such views. In the last decades, Western party systems were hit by rising abstention rates, a consistent decline in support for political parties, and a generalized public sentiment of scepticism towards politics. Finding that party leaders have the potential to compensate for at least some of these malaises by being able to reconnect dealigned citizens with active political participation can make a case for a positive normative outlook on the personalization of politics.

Importantly, the results appear quite robust and do not seem to be much affected by possibly intervening features of the countries' electoral systems which could play against leader effects on turnout. More personalized electoral systems, prone to a decentralized type of personalization, seem relatively unimportant in moderating the relationship between leader effects and turnout. As per the political system's characteristics, leader effects seem to be slightly hindered by semi-presidential regimes. A possible explanation relates to this system's dual executive nature, which may overshadow party leaders' role as fundamental actors.

This study opens some avenues for further research on the topic. First, following the mobilizing potential just described, regarding its positive normative consequences, it 
would be interesting to determine which aspects of voters' assessments of candidates drive them to turnout. Are these voters triggered by apolitical features or can leaders communicate party platforms more efficiently, vouch for a competent government leadership or even voice voters' demands in their public interventions in a way that develops a more personal identification than with regard to a political party? From a normative perspective, in principle, it can be claimed that if leaders have the potential to bring more individuals to participate in democratic elections, particularly in a context of decreasing turnout, the personalization of politics can carry positive consequences. However, if rather than leaders' performance-related characteristics, these individuals are driven to vote by superficial and apolitical judgements of leaders, such positive normative consequences can be questioned. An exploratory study by Silva \& Costa (2018) has shed some light on this, but more extensive research is needed.

Second, additional research with the use of panel data could allow for a better perception of the role of leader evaluations in fostering turnout across time, that is, to what has this variable been becoming more relevant over the past decades - in parallel with the process of dealignment - in comparison with long-term determinants of turnout. Naturally, given the scarcity of panel data, this could only be achieved in respect to fewer countries than the ones analysed here.

Third, it would be relevant to expand on the current exploratory section on the moderating role of contextual variables. It would be interesting to consider different party types (although such data is frequently hard to obtain) or the type of electoral system (majoritarian, proportional, two-party), for example. Such analysis could provide a more nuanced account of to what extend and under which circumstances do leaders matter more for electoral participation. 


\section{Acknowledgements:}

This researched has been financed by the Fundação para a Ciência e Tecnologia research grant SFRH/BD/52671/2014.

The author would like to thank Alexander H. Trechsel, Diego Garzia, the participants of the II Leuven-Montréal Winter School on Elections (2017) for their valuable feedback on earlier versions of this article. The acknowledgments are extended to the two anonymous reviewers and the editor of Electoral Studies for their comments and suggestions. 


\section{REFERENCES}

Aarts, K., Blais, A. (2011). Pull or Push? Positive and Negative Leader Evaluations and Vote Choice. In Aarts, K., Blais, A., \& Schmitt, H. (Eds.) (2011). Political Leaders and Democratic Elections. Oxford: Oxford University Press.

Aarts, K., Blais, A., Schmitt, H. (Eds.) (2011). Political Leaders and Democratic Elections. Oxford: Oxford University Press.

Adams, J., Dow, J., Merrill, S. (2006). The Political Consequences of Alienation-Based and Indifference-Based Voter Abstention: Applications to Presidential Elections. Political Behavior, 28(1): 65-86.

Aldrich, J., McKelvey, R. (1977). A Method of Scaling with Applications to the 1968 and 1972 Presidential Elections. The American Political Science Review, 71 (1): 111-130

Balmas, M., Rahat, G., Sheafer, T., Shenhav, S. (2012). Two Routes to Personalized Politics: Centralized and decentralized personalization. Party Politics, 20 (1): 37-51

Bittner, A. (2011). Platform or Personality? Oxford: Oxford University Press.

Bittner, A. (2015). Leader Evaluations and Partisan Stereotypes: a comparative analysis. In M. C. Lobo \& J. Curtice (Eds.), Personality Politics? The Role of Leader Evaluations in Democratic Elections. Oxford: Oxford University Press.

Blais, A. (2014). Why is Turnout So Low in Switzerland? Comparing the Attitudes of Swiss and German Citizens Towards Electoral Democracy. Swiss Political Science Review, 20 (4): 520-528

Blais, A., Rubenson, D. (2013). The Source of Turnout Decline: New Values or New Contexts?. Comparative Political Studies, 46 (1): 95-117 
Campbell, A., Converse, P., Miller, W., Stokes, D. (1960). The American Voter. Chicago: University Of Chicago Press.

Curtice, J., Hunjan, S. (2011). Elections as Beauty Contests: Do Rules Matter?. In K. Aarts, A. Blais, and H. Schmitt (Eds.), Political Leaders and Democratic Elections. Oxford: Oxford University Press.

Curtice, J., Lisi, M. (2015). The Impact of Leaders in Parliamentary and Presidential Regimes. In M. C. Lobo \& J. Curtice (Eds.), Personality Politics? The Role of Leader Evaluations in Democratic Elections. Oxford: Oxford University Press.

Cross, W., \& Pilet, J. (2016). The Politics of Party Leadership: A Cross-national Perspective. Oxford University Press.

Dalton, R. J. (2002). The Decline of Party Identifications. In R. J. Dalton \& M. P. Wattenberg (Eds.), Parties Without Partisans. Oxford: Oxford University Press.

Dalton, R. J., Wattenberg, M. P. (Eds). (2002). Parties Without Partisans: Political Change in Advanced Industrial Democracies. Oxford: Oxford University Press.

Dalton, R. J. (2012). The Apartisan American: Dealignment and Changing Electoral Politics. Thousand Oaks, CA: CQ Press.

Downs, A. (1957). An Economic Theory of Democracy. New York, NY: Harper \& Bros.

Elgie, R. (2011). Semi-Presidentialism: sub-types and democratic performance. Oxford: Oxford University Press

Elgie, R. (2017). Up-to-date list of semi-presidential countries with dates. Retrieved from http://www.semipresidentialism.com/?p=1053

European Commission (2013). Commission Recommendation of 12 March 2013 on enhancing the democratic and efficient conduct of the elections to the European 
Parliament (2013/142/EU). Available at: http://eur-lex.europa.eu/legalcontent/EN/TXT/?uri=uriserv:OJ.L_.2013.079.01.0029.01.ENG (accessed 19 January 2017)

Fiorina, M. P. (1981). Retrospective Voting in American National Elections. New Haven: Yale Univ Press.

Garzia, D. (2013). Changing parties, changing partisans. The Personalization of Party Attachments in Western Europe. Political Psychology, 34: 1: 67-89.

Garzia, D. (2014). Personalization of Politics and Electoral Change. London: Palgrave Macmillan.

Garzia, D., De Angelis, A. (2016). Partisanship, leader evaluations and the vote: Disentangling the new iron triangle in electoral research. Comparative European Politics, 14: 5: 604-625.

Garzia, D., Silva, F. F., De Angelis, A. (2018). Partisan Dealignment and the Personalization of Politics in Western Parliamentary Democracies, 1961-2016. UC Irvine: Center for the Study of Democracy. Retrieved from https://escholarship.org/uc/item/8r7500zq

Gidengil, E. (2011). Voter Characteristics and Leader Effects. In K. Aarts, A. Blais, and H. Schmitt (Eds.), Political Leaders and Democratic Elections. Oxford: Oxford University Press.

Hare, C., Armstrong II, D., Bakker, R., Carroll, R., Poole, K. (2015). Using Bayesian Aldrich-McKelvey Scaling to Study Citizens' Ideological Preferences and Perceptions. American Journal of Political Science, 59 (3): 759-774 
Hazan, R., \& G. Rahat. (2010). Democracy within Parties. Oxford: Oxford University Press.

Holmberg, S.,Oscarsson, H. (2011). Party Leader Effects on the Vote. In K. Aarts, A. Blais, and H. Schmitt (Eds.), Political Leaders and Democratic Elections. Oxford: Oxford University Press.

Karvonen, L. (2010). The Personalization of Politics. Colchester: European Consortium for Political Research Press.

Kenig, O. (2009). Democratization of party leadership selection: Do wider selectorates produce more competitive contests?. Electoral Studies, 28(2): 240-247.

Kentmen-Cin, C. (2017). What about Ambivalence and Indifference? Rethinking the Effects of European Attitudes on Voter Turnout in European Parliament Elections. Journal of Common Market Studies, 55 (6): 1343-1359

Kriesi, H. (2012). Personalization of National Election Campaigns. Party Politics, 18(6): $825-844$

Lachat, R. (2015). Leader Effects and Party Polarization. In M. C. Lobo \& J. Curtice (Eds.), Personality Politics? The Role of Leader Evaluations in Democratic Elections. Oxford: Oxford University Press.

Lavine, H. G., Johnston, C. D., \& Steenbergen, M. R. (2012). The Ambivalent Partisan: How Critical Loyalty Promotes Democracy. New York, NY: Oxford University Press.

Lewis-Beck, M. Nadeau, R., Elias, A. (2008). Economics, Party, and the Vote: Causality Issues and Panel Data. American Journal of Political Science, 52 (1): 84-95 
Lisi, M., Santana-Pereira, J. (2014). Campaign Individualisation before and after the Bailout: A Comparison between Greece and Portugal. South European Society and Politics, 19(4): 541-559.

Lobo, M. C. (2008). Parties and Leader Effects: Impact of Leader in the Vote for Different Types of Parties. Party Politics, 14 (3): 281-298

Lobo, M. C. (2015). Party Dealignment and Leader Effects. In M. C. Lobo and J. Curtice (Eds.), Personality Politics? The Role of Leader Evaluations in Democratic Elections. Oxford: Oxford University Press.

Lobo, M. C., Curtice, J. (Eds.) (2015). Personality Politics?: The Role of Leader Evaluations in Democratic Elections. Oxford University Press. Mughan, A. (2015). Parties, conditionality and leader effects in parliamentary elections. Party Politics, 21 (1): 28-39

Poguntke, T., Webb, P. (2005) The Presidentialization of Politics: a comparative study of modern democracies. Oxford: Oxford University Press

Renwick, A. Pilet, J. (2016). Faces on the Ballot: The Personalization of Electoral Systems in Europe. Oxford University Press.

Sartori, G. (1997). Comparative Constitutional Engineering: an enquiry into structures, incentives, and outcomes. New York, NY: New York University Press

Schmitt, H., Hobolt, S., Popa, S. A. (2015). Does personalization increase turnout? Spitzenkandidaten in the 2014 European Parliament elections. European Union Politics, 16(3): 347-368.

Silva, F. F., Costa, P. (2018). Do we need warm leaders? An exploratory study of the role of voter evaluations of leaders' traits on turnout on seven European countries. European Journal of Political Research, doi: 10.1111/1475-6765.12273 
Smets, K., van Ham, C. (2013). The embarrassment of riches? A meta-analysis of individual-level research on voter turnout. Electoral Studies, 32(2): 344-359.

The Comparative Study of Electoral Systems (www.cses.org). CSES MODULE 3 FULL RELEASE [dataset]. December 15, 2015 version. doi:10.7804/cses.module3.2015-12-15 The Comparative Study of Electoral Systems (www.cses.org). CSES MODULE 4 FULL RELEASE [dataset]. May 29, 2018 version. doi:10.7804/cses.module4.2018-05-29

Wattenberg, M. P. (1991). The Rise of Candidate-Centered Politics: Presidential Elections of the 1980s. Harvard: Harvard University Press.

Wattenberg, M. P. (2002). The Decline of Party Mobilization. In In R. J. Dalton and M. P. Wattenberg (Eds.), Parties Without Partisans. Oxford: Oxford University Press.

Wauters, B., Thijssen, P., van Aelst, P., Pilet, J-B. (2016). Centralized personalization at the expense of decentralized personalization. The decline of preferential voting in Belgium (2003-2014). Party Politics. doi: https://doi.org/10.1177/1354068816678882

Wilke, J., Reinemann, C. (2001). Do the Candidates Matter? Long-term Trends of Campaign Coverage - A Study of the German Press Since 1949. European Journal of Communication, 16(3): 291-314.

Zittel, T., Gschwend, T. (2008). Individualized Constituency Campaigns in MixedMember Electoral Systems: Candidates in the 2005 German Elections. West European Politics, 31(5): 978-1003. 


\section{Appendix}

1. List of countries and election studies included

Country

Election year

Austria

2008
2013

Bulgaria

2014

Croatia

2007

Czech Republic

2006

2010

2013

Denmark

2007

2011

Finland

2007

2011

2015

France

2007

2012

Germany

Slovakia
1442

2002

1857

1653

2007

2011

Portugal

1000

\section{Country}

Election year

$\mathrm{N}$

\section{Latvia}

$\begin{array}{ll}2010 & 1005 \\ 2011 & 1004 \\ 2013 & 1036\end{array}$

Montenegro

$$
2012
$$

967

Netherlands

$\begin{array}{ll}2006 & 2359 \\ 2010 & 2153\end{array}$

Norway

Poland

$\begin{array}{ll}2005 & 2402 \\ 2007 & 1817 \\ 2011 & 1919\end{array}$

$2009 \quad 1316$

$2015 \quad 1499$

Serbia

1238

2012

1568

1298

1587

Slovenia

2000

2008

1055

2011

1031 


\begin{tabular}{|c|c|c|c|}
\hline 2005 & 2018 & 2010 & 1203 \\
\hline 2009 & 2095 & 2016 & 1150 \\
\hline 2013 & 1889 & & \\
\hline Iceland & \multicolumn{2}{|c|}{ Spain } & \\
\hline 2007 & 1595 & 2008 & 1204 \\
\hline 2009 & 1385 & 2011 & 6082 \\
\hline 2013 & 1479 & & \\
\hline Ireland & \multicolumn{3}{|c|}{ United Kingdom } \\
\hline 2007 & 1435 & 2010 & 1577 \\
\hline 2011 & 1853 & 2015 & 1567 \\
\hline Italy & \multicolumn{3}{|c|}{ United States } \\
\hline \multirow[t]{2}{*}{2013} & 1508 & 2008 & 2102 \\
\hline & & 2012 & 1929 \\
\hline
\end{tabular}


2. Summary measures of the variables included in the models

Std.

Min. Max. Mean

deviation

Turnout - (0: Did not vote; 1 : Voted $)$

Age - Numeric

$\begin{array}{llll}16 & 106 & 48.42 & 17.45\end{array}$

Age (groups) - (1: Less than 30; 2: 30-39; 3: 40-49;

4: 50-59; 5: 60-69; 6: More than 70)

Gender - (1: Male; 2: Female)

$\begin{array}{llll}1 & 2 & 1.52 & .50\end{array}$

Education - (1: No formal education; 2: Primary

education; 3: Secondary education; 4: Tertiary

$\begin{array}{llll}1 & 4 & 2.84 & .78\end{array}$

education)

Org. member - (0: Not a member; $1:$ Member $)$

$\begin{array}{lll}0 & 1 & .25\end{array}$

.44

Pol. Efficacy - (1: Who people vote for won't

make a difference; 5: Who people vote for can

$\begin{array}{lll}1 & 5 & 3.72\end{array}$

1.30

make a big difference)

Strength of PID - (0: No PID; 1: Not very close; 2 :

Somewhat close; 3: Very close)

Pol. Sophistication - (0: No correct answers; 1:

One correct answer; 2: Two correct answers; 3:

$\begin{array}{llll}0 & 3 & 1.51 & 1.01\end{array}$

Three correct answers)

Previous turnout - (0: Did not vote in the previous

election; 1: Voted in the previous election)

$\begin{array}{llll}0 & 1 & .83 & .38\end{array}$

Party evaluations - (0: Does not like the party; 10:

Likes the party)

$\begin{array}{llll}0 & 10 & 7.70 & 2.08\end{array}$ 
Leader evaluations - (0: Does not like the leader;

10: Likes the leader)

$\begin{array}{llll}0 & 10 & 7.66 & 2.02\end{array}$

Political system - (0: Parliamentary; 1: Semi-

Presidential; 2: Presidential)

$\begin{array}{llll}0 & 2 & .61 & .58\end{array}$

District size - Numeric

$\begin{array}{llll}0 & 150 & 22.65 & 40.33\end{array}$

Personalized vote $-(0$ : Not allowed; 1: Allowed $) \quad \begin{array}{lllll}0 & 1 & .48 & .50\end{array}$ 
3. Comparison of the marginal effects for key variables of model 4, with and without turnout on the previous election

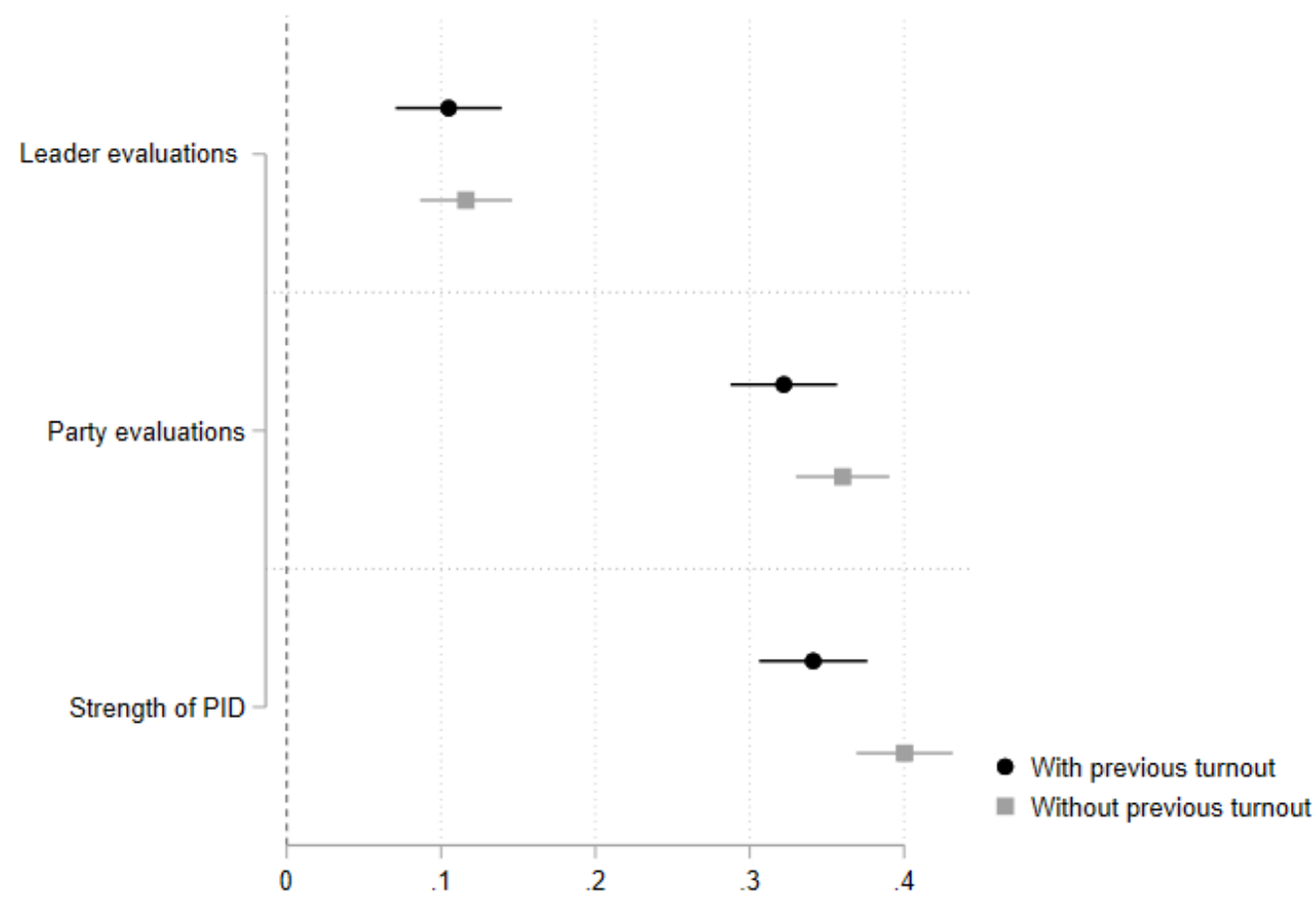


4. Logistic regression with fixed country effects (25 countries) - Dichotomous measure of PID - standardized coefficients, model 5

OR OR 95\% CI

\begin{tabular}{|c|c|c|}
\hline \\
\hline \multicolumn{2}{|l|}{$\begin{array}{l}\text { Age (groups) } \\
\text { Ref. category = Less than } 30\end{array}$} & $1.04-1.23$ \\
\hline $40-49$ & $1.41 * * *(.06)$ & $1.29-1.54$ \\
\hline $50-59$ & $1.62 * * *(.08)$ & $1.48-1.77$ \\
\hline $60-99$ & $1.98 * * *(.10)$ & $1.79-2.18$ \\
\hline More than 70 & $1.69 * * *(.09)$ & $1.52-1.88$ \\
\hline Gender & $1.01(.03)$ & $.96-1.07$ \\
\hline Education & $1.36 * * *(.03)$ & $1.31-1.42$ \\
\hline Political efficacy & $1.30 * * *(.01)$ & $1.27-1.33$ \\
\hline Dichotomous PID & $2.25 * * *(.25)$ & $1.82-2.79$ \\
\hline Org. membership & $1.30 * * *(.05)$ & $1.20-1.40$ \\
\hline Pol. sophistication & $1.35 * * *(.02)$ & $1.31-1.40$ \\
\hline Turnout on the previous & $8.70 * * *(.90)$ & $7.11-10.64$ \\
\hline election & & \\
\hline Party evaluations & $1.18 * * *(.01)$ & $1.16-1.20$ \\
\hline Leader evaluations & $1.10 * * *(.01)$ & $1.08-1.13$ \\
\hline Leader*Dichotomous PID & $.96 *(.01)$ & $.94-.99$ \\
\hline Leader*Previous turnout & $.95 * *(.01)$ & $.93-.98$ \\
\hline$N$ & & \\
\hline AIC & & \\
\hline
\end{tabular}


$* p<.05 ; * * p<.01 ; * * * p<.001$

Standard errors between parenthesis

5. Marginal effects of most liked and disliked leaders, while controlling for most disliked and most liked leaders, respectively - absolute and relative measurements. Fixed country effects logistic regression (25 countries) - standardized coefficients, model 4.

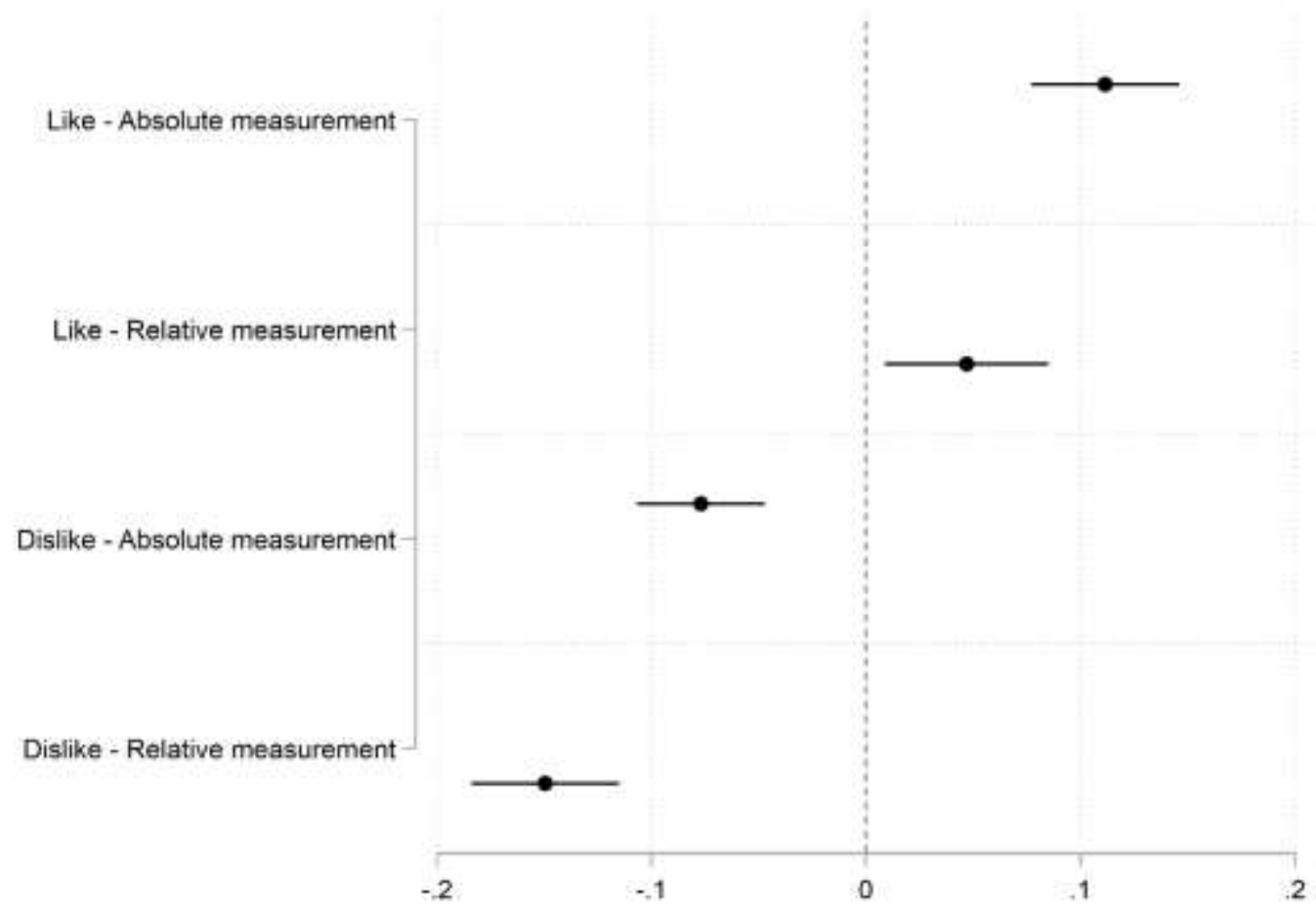


6. Leave-one-out cross-validation tests (LOOCV) for the effect of leader evaluations on turnout (model 4)




7. Leave-one-out cross-validation tests (LOOCV) for the interaction effect between leader evaluations and turnout on the previous election on turnout (model 5)

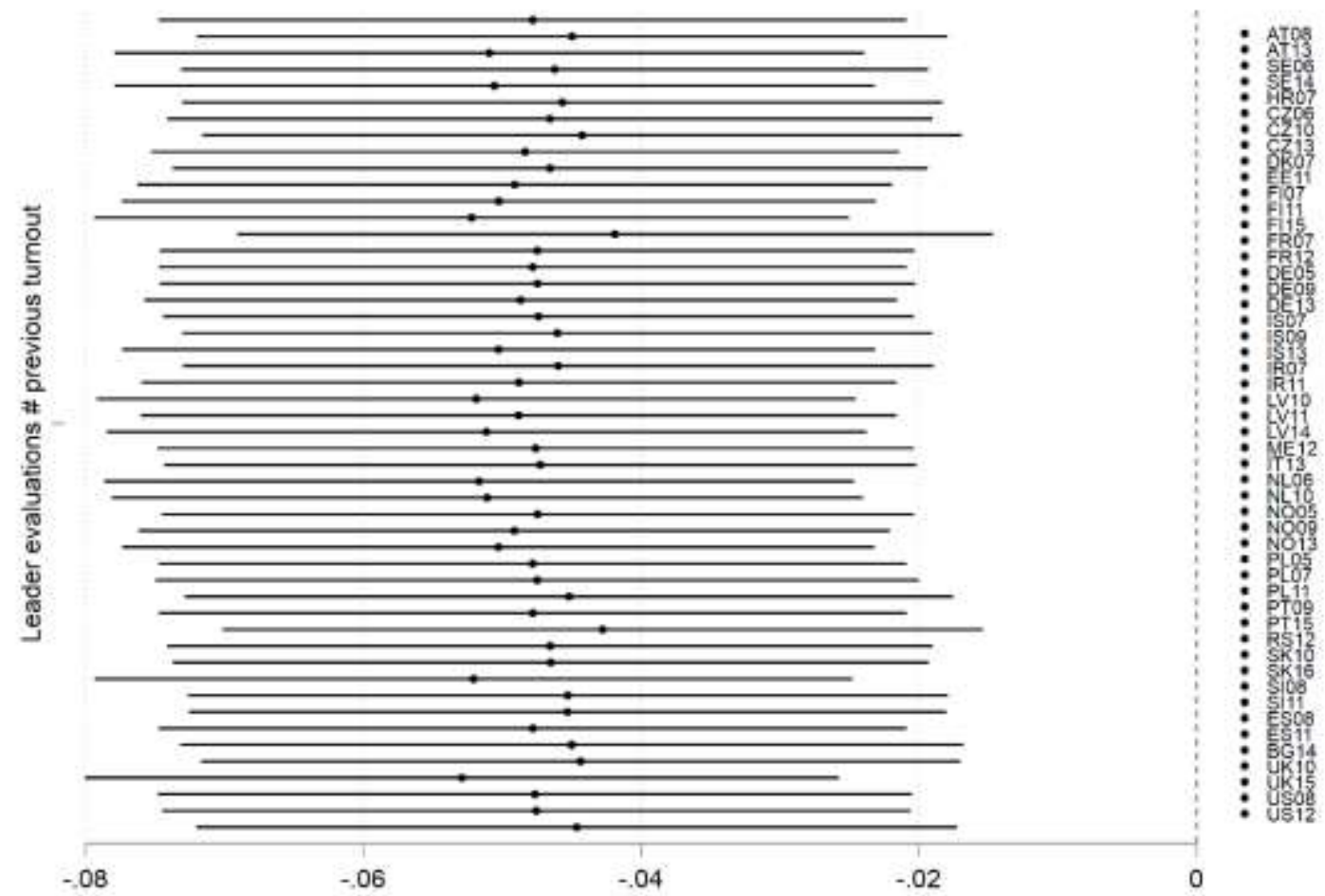


8. Leave-one-out cross-validation tests (LOOCV) for the interaction effect between leader evaluations and strength of party identification on turnout (model 5)

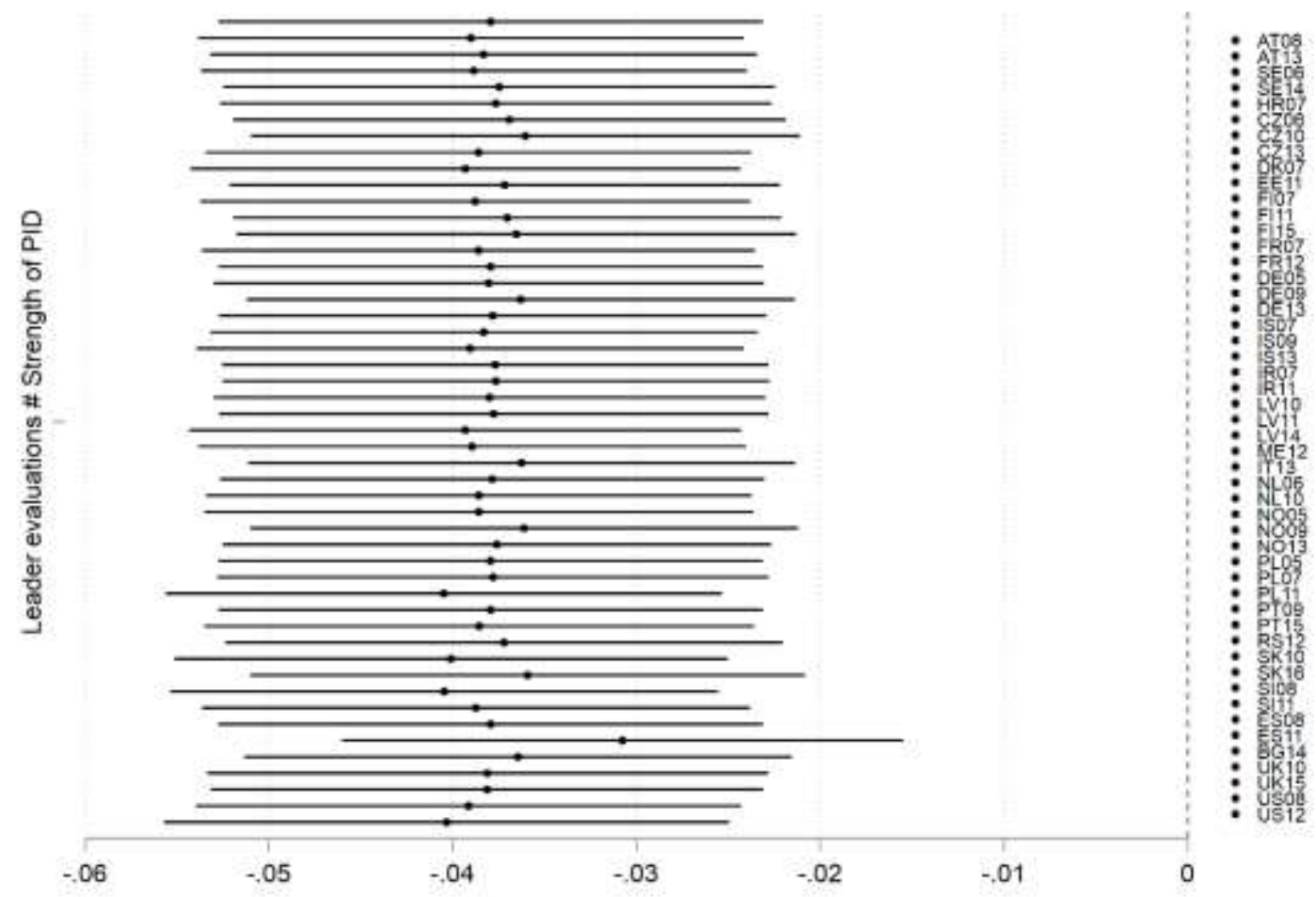


9. Leave-one-out cross-validation tests (LOOCV) for the interaction effect between leader evaluations and political sophistication on turnout (model from appendix 10)

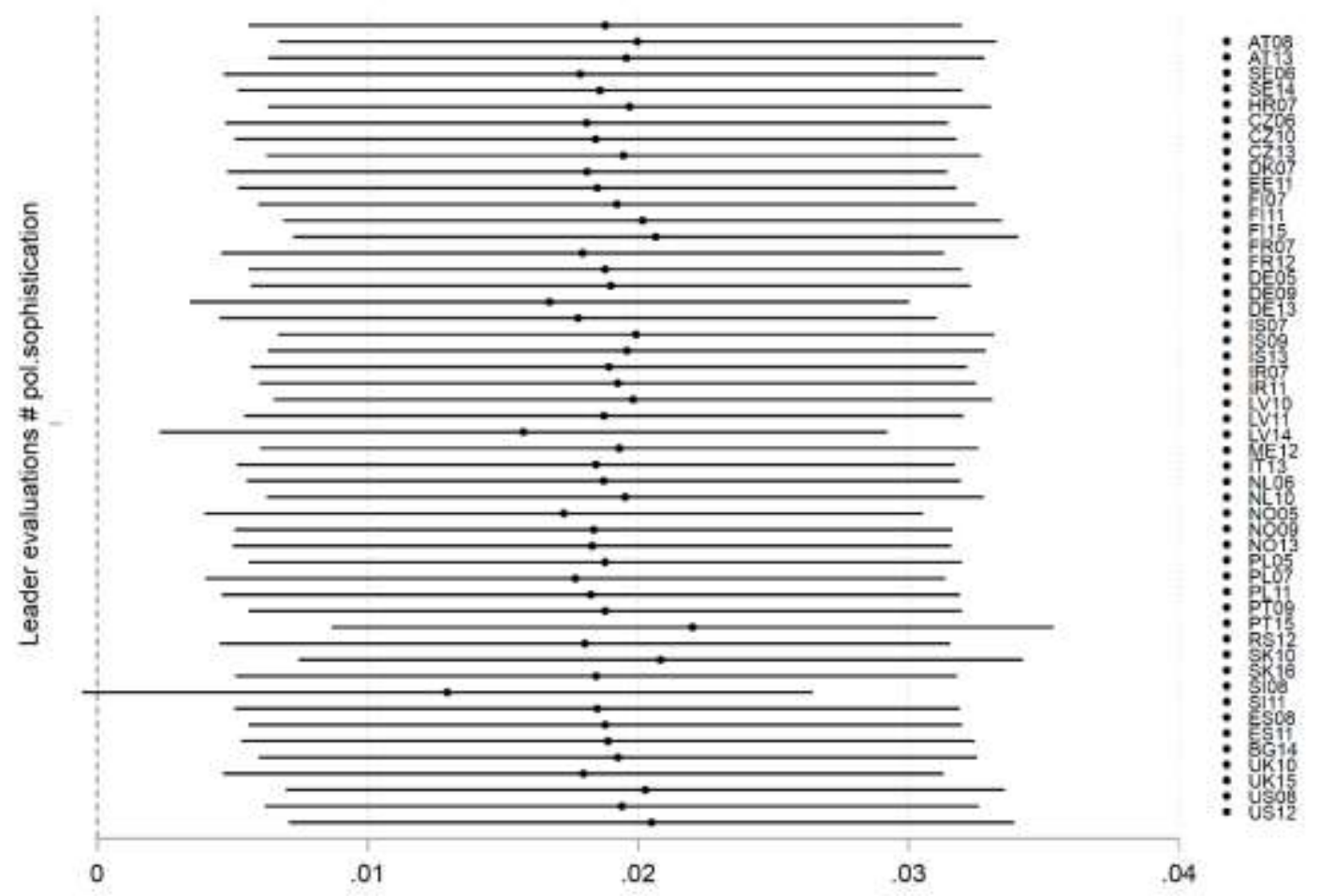


10. Logistic regression with fixed country effects (25 countries) - Interaction between leader evaluations and political sophistication, standardized coefficients

\section{OR OR 95\% CI}

Age

Ref. Category $=$ Less than 30

$\begin{array}{lll}30-39 & 1.13 * *(.05) & 1.03-1.23 \\ 40-49 & 1.39 * * *(.06) & 1.27-1.53 \\ 50-59 & 1.58 * * *(.07) & 1.44-1.74 \\ 60-99 & 1.93 * * *(.10) & 1.75-2.13 \\ \text { More than } 70 & 1.63 * * *(.09) & 1.46-1.81\end{array}$

Gender

$1.02(.03) \quad .97-1.08$

Education

$1.36^{* * *}(.03) \quad 1.31-1.41$

Political efficacy

$1.29 * * *(.01) \quad 1.26-1.31$

Strength of PID

$1.87 * * *(.01) \quad 1.66-2.12$

Org. membership

$1.28 * *(.05) \quad 1.19-1.38$

Pol. Sophistication

$1.17 * *(.06) \quad 1.07-1.30$

Turnout on the previous election

$8.92 * * *(.92) \quad 7.28-10.92$

Party evaluations

$1.16^{* * *}(.01) \quad 1.15-1.18$

Leader evaluations

$1.09 * * *(.02) \quad 1.06-1.12$

Leader*Strength of PID

$.96^{* * *}(.01)$

$.95-.98$

Leader*Political Sophistication

$1.02 * *(.06)$

$1.06-1.30$

Leader*Previous turnout

$.95 * *(.01)$

$.93-.98$

$N$ 
McFadden's R2

AIC

BIC
.29

35617.9

36175.59 